\title{
Testing the "(Neo-)Darwinian" Principles against Reticulate Evolution: How Variation, Adaptation, Heredity and Fitness, Constraints and Affordances, Speciation, and Extinction Surpass Organisms and Species
}

\author{
Nathalie Gontier \\ Applied Evolutionary Epistemology Lab, Centro de Filosofia das Ciências, Departamento de História e Filosofia \\ das Ciências, Faculdade de Ciências, Universidade de Lisboa, 1749-016 Lisboa, Portugal; nlgontier@fc.ul.pt \\ Received: 2 March 2020; Accepted: 19 June 2020; Published: 5 July 2020 \\ check for \\ updates
}

\begin{abstract}
Variation, adaptation, heredity and fitness, constraints and affordances, speciation, and extinction form the building blocks of the (Neo-)Darwinian research program, and several of these have been called "Darwinian principles". Here, we suggest that caution should be taken in calling these principles Darwinian because of the important role played by reticulate evolutionary mechanisms and processes in also bringing about these phenomena. Reticulate mechanisms and processes include symbiosis, symbiogenesis, lateral gene transfer, infective heredity mediated by genetic and organismal mobility, and hybridization. Because the "Darwinian principles" are brought about by both vertical and reticulate evolutionary mechanisms and processes, they should be understood as foundational for a more pluralistic theory of evolution, one that surpasses the classic scope of the Modern and the Neo-Darwinian Synthesis. Reticulate evolution moreover demonstrates that what conventional (Neo-)Darwinian theories treat as intra-species features of evolution frequently involve reticulate interactions between organisms from very different taxonomic categories. Variation, adaptation, heredity and fitness, constraints and affordances, speciation, and extinction therefore cannot be understood as "traits" or "properties" of genes, organisms, species, or ecosystems because the phenomena are irreducible to specific units and levels of an evolutionary hierarchy. Instead, these general principles of evolution need to be understood as common goods that come about through interactions between different units and levels of evolutionary hierarchies, and they are exherent rather than inherent properties of individuals.
\end{abstract}

Keywords: philosophy of biology; modern synthesis; extended synthesis; Darwinian principles; natural selection; variation; adaptation; heredity; fitness; constraints; affordances; speciation; extinction; reticulate evolution; symbiosis; symbiogenesis; lateral gene transfer; hybridization; infective heredity; mobile genetic elements

\section{Introduction}

Both the Modern Synthesis as well as the Neo-Darwinian paradigm study evolution as it occurs by means of natural selection by investigating the nature of phenomena such as variation, adaptation, heredity and fitness, constraints and affordances, speciation, and extinction [1]. These phenomena are deemed sufficient to explain the origin and evolution of species, and several of them have been characterized as "Darwinian principles" [2].

Here, we suggest that caution should be taken in calling these principles Darwinian because of the important role played by reticulate evolutionary mechanisms and processes in also bringing 
about these phenomena. Firstly, in contrast with conventional (Neo-)Darwinian theories, reticulate evolution demonstrates that these principles cannot solely be understood as intra-species features of evolution because they frequently involve reticulate interactions between organisms belonging to very different taxonomic categories. Secondly, the fact that reticulate mechanisms and processes shape the evolutionary trajectories of genes, organisms, species, and ecosystems by also operating on and along these principles demonstrates that the principles are much more universal than previously thought. This in turn provides hope for the construction of an integrative and pluralistic evolutionary theory that is able to include both reticulate and vertical evolutionary pathways and that recognizes the principles as objective and neutral markers of both types of evolution.

This work is divided into three Sections. In Section 2, a general definition of reticulate evolution is provided and then the common ways whereby reticulate evolution occur in nature are outlined. These include symbiosis and symbiogenesis, lateral gene transfer, infective heredity, and hybridization. In Section 3, it is exemplified how all six principles that have been designated as "Darwinian" (variation, survival and adaptation, heredity and fitness, constraints and affordances, speciation, and extinction) are also brought forth by the ways whereby reticulate evolution occurs. Finally, in Section 4 , the implications of these findings for evolutionary epistemologies are discussed.

\section{Reticulate Evolution}

Reticulate evolution studies track how over the course of ontogeny, non- or distinctly related entities interact in such a way that it impacts phylogeny. Reticulate interactions can occur through symbiosis [3,4], symbiogenesis [5-10], lateral gene transfer [11,12], infective heredity [13] mediated by mobile genetic elements $[14,15]$ and overall organismal mobility, and hybridization $[16,17]$.

Hybridization is the only form of reticulation that occurs through sexual recombination. During hybridization, organisms belonging to different species mate, resulting in offspring that carries the chromosomal DNA of both species. Other forms of reticulation occur when genes, gene sets, and even organisms in their entirety become horizontally exchanged without the interacting individuals engaging in sexual reproduction with one another.

During lateral gene transfer, bacteria can incorporate in their cytoplasm extrachromosomal DNA such as plasmids coming from other bacteria, or they can incorporate foreign genes into their bacterial chromosome. Reticulate interactions can also take on the form of contagions, when bacteria or eukaryotic organisms become infected with viruses. Viral infections can lead to the destruction of the host, but some viruses can integrate their genes into the host's genome where they can become passed on to following generations. Multicellular organisms can even acquire entire other organisms, such as bacteria or protozoa, and, together, the host and its symbionts then function as a new entity, the holobiont $[18,19]$.

Ontogenetically acquired symbiotic interactions can have a long-term impact on the life course of the interacting organisms as well as on the future course of evolution of their progeny. This is because the symbiotic interactions can become repeated each generation anew. Some symbiotic interactions can also become permanently inherited, in which case it is called hereditary symbiosis [20]. Hereditary symbiosis can lead to symbiogenesis, which denotes evolution by cell fusion. Symbiogenesis played an important role in the formation of eukaryotic cell organelles. Reticulate symbiotic interactions can also alter the course of evolutionary history without there occurring genetic or organismal integration of symbionts into their host. The pollination of flowering plants by bees or wasps, for example, happens by surface contact.

Modeling of the horizontal and reticulate interactions between distinct lineages brings forth network diagrams [21] rather than branching diagrams where existing lineages ramify into new ones. Advocates of the important role that reticulate evolution plays in life therefore argue that the Darwinian tree-of-life metaphor should be complemented if not replaced with a web-of-life metaphor [22].

Beneath, a brief review is given on how symbiosis and symbiogenesis (Section 2.1), lateral gene transfer (Section 2.2), infective heredity (Section 2.3), and hybridization (Section 2.4) bring forth 
reticulate evolution. In the following, it is exemplified how these forms of reticulate evolution affect all six "Darwinian principles".

\subsection{Symbiosis and Symbiogenesis}

Symbiosis and symbiogenesis are discussed conjointly here and throughout the paper because they are closely related phenomena that can both impact the future course of evolution.

\subsubsection{Symbiosis}

Symbiosis is a term introduced by de Bary [3] to designate the living in close association of "unlike-named organisms" [23-29]. Symbiosis refers to the phenomenon where two or more organisms with distinct genealogical, evolutionary histories either form conjunctive (morphologically connecting) or disjunctive (ecological) associations [30,31]. When the association is conjunctive, the smaller organism is called the symbiont and the larger partner is called the host.

Beyond the conjunctive-disjunctive distinction, scholars further differentiate symbiotic associations based upon the following criteria.

1. The nature of the symbiosis: Symbiosis is a term that indicates interaction, but it does not specify the precise nature of the interaction which can be beneficial (+), harmful (-), or neutral (0) for either or all of the interacting organisms. In this regard, van Beneden [4,32] distinguished between mutualism $(+,+$ for both organisms), commensalism $(+, 0)$, and parasitism $(+,-)$. These concepts were first used in nutritional and social contexts, but they are also extendable to ecological situations. Later, Toynbee [33] added the notion of synnecrosis (-,-), and Haskell [34] (p. 46) added amensalism $(-, 0)$ and neutralism $(0,0)$ to the spectrum of possible symbiotic interactions.

2. The necessity of the symbiosis: Symbiotic associations can be obligate or facultative [4,32].

3. The temporality of the symbiosis: Symbiotic associations can become established each generation anew during ontogeny, they can extend for particular and possibly repetitive or cyclic periods in time, and they can become permanent and hereditary [34,35], in which case the associating partners come to rely on one another for successful survival and possibly reproduction. Symbiosis has long been considered an ecological or developmental phenomenon only, but today eco-evo-devo schools are demonstrating how ecology and development can impact evolution, and especially hereditary symbiosis demonstrates how symbiosis can have a lasting impact on phylogeny.

4. The location of the symbiont in relation to its host: In disjunctive symbiosis, organisms simply occupy the same space without necessarily engaging in physical contact. In conjunctive symbiosis, the symbiont can live on (ectosymbiosis) or inside (endosymbiosis) the host (e.g., in the lungs or the gut), or it can live inside the host' cells (intracellular symbiosis) [36-38].

5. The mode whereby hosts acquire symbionts: Symbiont acquisition occurs through contact (cell collisions, phagocytosis, eating, touch, birthing, respiration, etc.) and symbionts can be transmitted both horizontally (during the lifetime of individual organisms) or vertically (over generations of individuals through time) through a variety of mechanisms and processes [7,9].

Per definition, symbiosis refers to associations between living organisms [28], but non-living genetic agents such as viruses [39,40], infectious proteins such as prions [41], and mobile genetic elements [14,42] can also be understood as symbionts once they enter a host [13]. The host together with its (multiple) symbiont(s) can be considered a new biological individual. The newly formed chimeric individual has variously been called a holobiont [18,19], a consortium [5,43,44], a superorganism [45-47], a holon [48], a symbiome 28 (p. 1047), [49] (p. 235), and a synergy [5,43]. The holobiont concept is developing into the more commonly-used concept and it was first introduced by Meyer-Abich as "holobiosis" [50,51]. Margulis [19] (p. 2) independently defined the holobiont as the sum of different bionts (living organisms). In association, Rosenberg and Zilber-Rosenberg [52] used the hologenome concept to refer to the sum of the host genome and its microbial genome and viriome. 


\subsubsection{Symbiogenesis}

Symbiogenesis $[5,6,8,53]$ is traditionally defined as evolution by permanent and hereditary symbiosis $[10,19,34-37,47]$. However, symbiotic associations can be inherited in quite a number of ways. Today, symbiogenesis is therefore often used more restrictively to refer to endosymbiosis or permanent cell fusions that underlie the formation of new cell structures, or new biological individuals.

Symbiogenesis played a crucial role in the transition from prokaryotes (unicellular organisms that lack a nucleus) to eukaryotes (uni- and multicellular organisms of which the cells have a nucleus) as well as in the formation of some of the most important eukaryotic cell organelles (distinct membrane-enclosed compartments in the cytoplasm of the cell). Mitochondria are cellular organelles found in most eukaryotic organisms that evolved from the incorporation of proteobacteria by early protists. Plant and algae cells additionally contain organelles called chloroplasts and these evolved from cyanobacteria. The acquisition of plastids in green and red algae and dinoflagellates is the result of several endosymbiotic events called primary, secondary, and tertiary endosymbiosis (reviewed in [54-56]).

Margulis [9] also asserted that the eukaryotic nucleus arose through symbiogenesis. Her Serial Endosymbiotic Theory suggests that this happened through the merger between archaea plasma and spirochetes. Other scholars disagree but nonetheless suggest a symbiogenetic origin for the eukaryotic nucleus. Martin, Garg and Zimorski [57] distinguished among 20 different versions of endosymbiosis theory. Livingstone Bell [58] suggested that the eukaryotic nucleus evolved from a DNA virus that entered methanogenic mycoplasma, while Villarreal and Witzany [40] emphasized the importance of viral agents as colonizers in the origin and diversification of the tree of life.

\subsection{Lateral Gene Transfer}

Lateral Gene Transfer is the process whereby organisms exchange genes asexually and horizontally, during ontogeny. Lateral gene transfer can occur between different gene-carrying entities residing inside the same cell (between the eukaryotic nucleus and organelles, for example, or between the bacterial chromosome and plasmids) or it can occur between organisms belonging to the same or different species, in turn belonging to different domains of life. Lateral gene transfer can occur in all possible directions, within and between prokaryotes, between prokaryotes and eukaryotes, and between eukaryotes $[11,12,59,60]$. Lateral gene transfer can also extend the realm of the living because it occurs between viruses and living organisms [40,61]. However, while all thinkable directions of genetic exchange are possible, there does exist variation in the ease and frequency whereby such exchanges occur $[62,63]$.

As a concept, lateral gene transfer is merely a container term for distinct mechanisms whereby genes can become exchanged horizontally. Known mechanisms whereby prokaryotes in particular exchange genetic material are transformation, conjugation, and transduction (Table 1).

Table 1. Major forms of lateral gene transfer in prokaryotes.

\begin{tabular}{ll}
\hline Transformation & The absorption of naked DNA from the environment through the cell \\
membrane [64,65]. & Transfer of plasmids through cell-to-cell contact. In Gram-negative bacteria, \\
a copy of the double-stranded plasmid of the donor bacterium is transferred \\
to a recipient bacterium, while, in Gram-positive bacteria, the entire plasmid \\
of the donor bacterium can become laterally transferred to a bacterial \\
recipient [66,67]. \\
During their lytic cycle [68], when bacteriophages destroy their host, \\
they accidentally package bacterial genes from their host and transmit these \\
to recipient bacteria upon infection [69-71].
\end{tabular}




\subsection{Infective Heredity}

Organisms belonging to all three domains of life are prone to become infected by viruses, bacteria, or other organisms. The role of infection in health and disease and its impact on evolution was first examined by Haldane [72], one of the founders of the Modern Synthesis, and later it was dubbed "infective heredity" by Zinder and Lederberg [70,73]. Although dependent upon mobile genetic elements, lateral gene transfer, and symbiosis, infective heredity is introduced here as a distinct type of reticulate evolution in order to emphasize the impact that ontological processes of immunology, health, and disease have on evolution by altering the survival chances and reproductive success of infected individuals.

Mobile genetic elements are infective agents that are distinguished into two not mutually exclusive classes: (1) those which mobilize DNA sequence elements to multiple locations throughout a cell's genome (transposons, transposable proviruses, retroviruses, and retrotransposons); and (2) those which transport or mobilize nucleic acid between cells (Type IV secretion systems, plasmids, viruses, GTA or Gene Transfer Agents, ICE or Integrative and Conjunctive Elements, exosomes). Both classes are complementary in evolutionary change $[14,15,42]$. The relocation of genetic elements within the genome can be understood as a form of self-infection, and the relocation of genes between cells facilitates lateral gene transfer. Both play an important role in health and disease.

Infections also often take on the form of parasitic or mutualist and commensal symbiotic associations between host and symbiont. Examples of parasitic infectious agents are bacteriophages, viruses, prions, bacteria, fungi, protozoan organisms such as amoebas, animals such as worms (e.g., helminths), or larvae and maggots of insects [13]. Such associations between host and parasite need not be binary. Rather, they can be meditated by third parties that serve as vectors for the transmission to the host of pathogens present in the symbiont. An example of the latter are mosquitos that parasitize on the blood of humans, and in so doing they also provide opportunity to symbionts residing inside the mosquito, such as malaria parasites or the dengue virus, to transmit to the human hosts [74]. Examples of mutual and commensal symbiotic relationships are provided by current microbiome and viriome studies that demonstrate the many beneficial and even co-evolutionary relationships that exists between the "immunological self" and the interacting symbionts [75-79].

\subsection{Hybridization}

First defined by Linnaeus in 1753 [80], hybridization exclusively occurs in sexually reproducing species, such as plants and animals, as well as fungi [81] and yeasts [82]. During hybridization, organisms belonging to distinct subspecies, species, families, and even orders, cross and produce offspring [83-87].

Hybridization can provide a fast way to reduce genetic fatigue of an existing species, and it can also rapidly contribute to speciation by providing a source of adaptive variation that can create barriers to gene flow [88]. Speciation can occur by cladogenesis, when hybrids are no longer able to reproduce with their parental species, or by anagenesis, when hybrids backcross because they remain sexually compatible with their parental species, a process called introgressive hybridization [89].

Hybrids can also be sterile which in animal species implies the end of the lineage. In plant species, however, when hybridization leads to sexual incompatibility with the parental as well as with other (hybrid) species, the hybrids continue to propagate via asexual forms of reproduction (this is further discussed in Section 3.5).

Finally, hybridization is also a medium whereby symbionts of one species can become horizontally transmitted to another (during the somatic contacts associated with sexual behavior, for example) and it can also provide opportunities for lateral gene transfer. 


\section{The "Darwinian" Principles and Reticulate Evolution}

This part exemplifies how reticulate evolution can alter all six "Darwinian" principles of variation (Section 3.1), adaptation (Section 3.2), heredity and fitness (Section 3.3), constraints and affordances (Section 3.4), speciation (Section 3.5), and extinction (Section 3.6). The examples given focus on well-known case studies of model organisms such as lichens, Azolla, E. coli, the Hawaiian bobtail squid, Wolbachia and its insect hosts, Louisiana Irises, and human microbiome studies. It should also be noted that the case studies discussed per principle often also exemplify how reticulate evolution brings forth the other principles. Alterations in variation, for example, often provide evolutionary constraints as well as evolutionary affordances that contribute to (un)successful survival and reproduction, which in turn impacts speciation and extinction. As is the case in real life, the principles often intertwine.

\subsection{Variation}

All types of reticulate associations contribute to the genetic, epigenetic, phenotypic (anatomical, physiological, immunological, and behavioral) variation found in individual organisms, which extends to the overall populations and species they belong too.

\subsubsection{Symbiosis and Symbiogenesis}

Margulis $[7,9]$ and other early advocates of symbiogenesis $[6,36-38,90]$ asserted that both symbiosis and symbiogenesis are the main means whereby novel variation arises on the grand scale of life. For them, symbiogenesis is what enabled eukaryotes to originate and to diversify into separate kingdoms [91], which then provided the genetic and phenotypic variation whereupon natural selection can act. As such, symbiogenesis precedes natural selection. The bacterial origin of mitochondria and chloroplasts not only contributed to the variation of eukaryotes, but has also drastically altered the morphological and genetic variation of the original entities that turned into organelles.

Beyond the origin of eukaryotic cells, ontogenetically acquired endo- and ectosymbiotic relations provide genetic and phenotypic variation that can have metabolic, behavioral, and reproductive effects on both the host and the symbiont. Lichens are by far the model organisms that contributed to recognizing the importance of symbiosis as a fact of nature [25,44]. Lichens are composite organisms made up of a fungus host (sometimes called the mycobiont) that has algae and/or cyanobacteria as symbionts (called photobionts because they photosynthesize). It is estimated that around one-fifth of all extant fungi entertain symbiotic relations with photobionts, and the symbiotic relations have been acquired and lost multiple times over, leaving an indelible mark on fungal evolution [92].

The symbiosis adds variation to the phenotype of both partners, and it is mutually beneficial. Through its photobionts, the fungus host receives an instant source of carbohydrates that it cannot produce by itself $[93,94]$. By engaging in symbiosis with the fungus, algae can expand their ecological habitats and increase their range of habitable zones of life. Algae normally live in aqueous environments but also find a suitable environment when in symbiosis with water-retaining fungi. In this case, they can also survive in dunes, on rocks or mountains, in woodlands, in rainforests, and even in extreme environments.

\subsubsection{Lateral Gene Transfer}

Mechanisms that underlie lateral gene transfer can increase the genetic variation of the recipient and reduce the genetic variation of the donor. Beyond evolving through symbiogenesis, mitochondria and chloroplasts for example have also repeatedly and laterally exchanged genes with the eukaryotic nucleus of the organisms they belong to $[95,96]$. Horizontal transfers from the nucleus to the organelle are rare, but transfers of genes from the organelles to the nucleus are quite common. This results in some of the functions originally performed by the organelles now being initiated from within the nucleus, by the migrated genes. 
Such relocations brought about by lateral gene transfer contribute to a reduction of the endosymbiont genome and it facilitates an overall orchestration of functional unity to the benefit of the cell and the entire organism. Explaining such alterations simply cannot be reduced to a genetic (nuclear or organellar) level. On the contrary, any such genetic exchange between organelles and nuclei brings to light the existence of higher-level entities such as the cell whose variation is altered because of the repeated genetic exchanges.

\subsubsection{Infective Heredity}

Upon infection, bacteriophages can take on a lysogenic (avirulent) phase that precedes the lytic (virulent) phase [68]. During the lytic phase, the phage uses the host metabolism to make more viral particles and it ends up destroying the host upon release. However, in their lysogenic phase, bacteriophages integrate into the host genome (a process known as lysogenization) at which point they are called prophages. As prophages, they act as symbionts, and the nature of the symbiosis can often be characterized as mutualistic.

An example is the lambda phage that infects E. coli bacteria [97]. During its lysogenic phase, the phage's DNA integrates into the bacterial genome of its E. coli host. In this condition, the phage finds shelter and protection from unfavorable environmental conditions, and the phage increases the genetic variation found in the host. It also increases metabolic and phenotypic variation of the E. coli bacterium, because some of the phage's genes are active, resulting in the bacterium demonstrating phenotypic properties it cannot produce by itself. An example is resistance to serum killing (animal blood contains antibacterial antibodies), which is a trait induced by genes coming from the lambda prophage, portrayed by the E. coli bacterium, which enables it to survive inside the bloodstream of numerous animals $[98,99]$.

Phage infection also contributes to the overall genetic variation of E. coli on a higher species level because, during division, the bacterial host passes on the integrated prophage genes to the next generation. This is also beneficial for lambda that, without any costs involved, is able to spread and increase in number each time lysogenic E. coli undergo division.

A special case of variation is attributed to mobile genetic elements [14] such as transposons, retrotransposons and retroviruses. Transposons and retrotransposons are found in both pro- and eukaryotes, and, in the latter, they have been implicated in numerous cancers as well as autoimmunity and neurodegenerative diseases [100]. Transposons or "jumping genes" [101,102] are mobile genetic elements that mostly cut themselves from their original site on the genome to subsequently integrate at a different location. Retrotransposons move about by a copy and paste mechanism [103], and thus duplicate.

When transposons integrate at a different location, they often alter or interrupt active genes and the metabolic pathways that these genes encode for. Rather than consider them as junk DNA, the inserted sequences are often sources of evolutionary innovation because they underlie novel metabolic features and phenotypic alterations (for a discussion, see [104]). Both transposons and retrotransposons thus alter existing variation, and they have the potential to introduce novel genetic interactions that in turn have the potential to introduce novel traits with phenotypic effects.

Other mobile genetic elements are endogenous retroviruses that have permanently integrated into the eukaryotic genome. As "gene delivery vectors" [105], they form an integrated part of the genome where they are passed on to future generations via sexual recombination, thereby contributing to the overall genetic variation of the species.

\subsubsection{Hybridization}

Hybridization increases variation at a genetic, phenotypic, sub-species, and species level [86]. Most certainly common in plants, an extensive review written by Arnold, Brothers, and Hamlin [106] also demonstrates the occurrence of hybridization in the following mammals: marsupials, rabbits and hares, mice, rats, chipmunks, minks and polecats, polar and brown bears, Florida panthers, 
South American wild cats, wild boars and domestic pigs, wildebeest, chamois, caribou, mule deer and black-tailed deer, dolphins, whales, horses, bats, lemurs, colobines, gorillas, chimpanzees, and bonobos.

One of the most fascinating cases of how hybridization can provide new variation involves the species admixture that occurred between Homo sapiens, Homo neanderthalensis, and other archaic Homo species. With the first draft of the Neanderthal genome, Green et al. [107] demonstrated that the genomes of non-African human populations carry around $2-4 \%$ of genes that stem from Neanderthal, Denisovan, and unidentified other archaic Homo species, a number that has since been reduced to around $2 \%[108,109]$. Later work also demonstrated that East Asian human populations carry higher levels of Neanderthal and Denisovan genes into their genomes than the European population and that also the Maasai of Africa carry Neanderthal genes $[110,111]$. Recent work has found that a little under $0.5 \%$ of Neanderthal DNA has integrated into the genomes of African populations [112]. The specific genes retained vary over populations and individuals, but, when taken together, the human population as a whole carries around $20 \%$ of Neanderthal DNA [113]. The genes acquired through hybridization associate with skin and light-reception features that enabled migrating African ancestors to adapt to colder Eurasian environments [114].

\subsection{Successful Survival and Adaptation}

All types of reticulation have the potential to impact successful survival and adaptation of all partners involved.

\subsubsection{Symbiosis and Symbiogenesis}

Symbiosis and symbiogenesis can induce phenotypic and epigenetic changes by providing or blocking nutrients, by introducing new genes and metabolic functions, or by inducing morphological and behavioral changes in the host or its symbionts that in turn impact successful survival and adaptation to their surroundings [26].

A well-documented example of how symbiosis can contribute to successful survival is the ontogenetically acquired, facultative symbiotic association that exists between nocturnal Hawaiian bobtail squids (Euprymna scolopes) and Gram-negative, luminescent Vibrio fischeri bacteria [115,116]. Both species have phylogenetically co-evolved the biochemical and behavioral means to recognize one another which enables an ontogenetic establishment of what remains a facultative symbiosis, commencing shortly after hatching, each generation anew. The squids, for example, evolved cilia at the end of their epithelia by which they circulate the water and harvest bacteria. Most of the bacteria acquired that way are killed by a mucus excreted by the squids. However, the Vibrio fischeri bacteria can resist the mucus and swim toward the crypts of the light organ. The squid nurtures the bacteria by providing it with a rich source of sugar and amino acids, and this makes the bacteria grow. When a critical threshold is reached, through quorum sensing, the entire group jointly commences luminescence [117-119].

The bacterial bioluminescence in turn provides counterillumination camouflage for the Hawaiian bobtail squid. By lighting up the bottom of the squid's body, the luminescent bacteria help mask the squid's shadow over the ocean floor at night, making it blend in with its environment which in turn enables it to avoid predation as well as to incognito hunt for food. In other words, the symbiotic relation contributes to successful survival of both partners. The squid constructs a niche for the bacteria, and the bacteria help build the light organ, and both ensure survival of the holobiont [120-123].

The squids can furthermore control the amount of light being emitted from the light organ that houses the luminescent bacteria, and the nature of the symbiosis also changes during day and nighttime. Because the symbiosis is costly for the nocturnal squid that feeds the bacteria, just before dawn, it ejects $90-95 \%$ of the luminescent bacteria into the surrounding marine environment. During the daytime, the light organ takes on different morphological and phenotypic traits, and the squid instead uses its ink sac as a defense. Just after dawn, the remaining $5 \%$ of Vibrio fischeri present in the light organ are biochemically enabled to repopulate and reintroduce the squid's bioluminescence [116,121]. 


\subsubsection{Lateral Gene Transfer}

Research has shown that bacterial antibiotic resistance [124] was acquired by horizontal gene transfer [71] and horizontal gene transfer has been argued to have facilitated the evolution of the major metabolic pathways that enable prokaryotes to survive [125].

\subsubsection{Infective Heredity}

Haldane [72] already investigated the impact that health and disease can have on intraspecific variation in humans, and how intraspecific variation in turn affects human evolution. He suspected there to exist a co-evolutionary relationship between hematological sickle cell states and protection against malaria that is induced by Plasmodium protozoa that are transmitted by mosquitos. Sickle cell anemia is a human red blood cell disease that can potentially be lethal, but an organism that has the sickle cell state without having the disease is better protected against malaria infection. Around 7\% of people who occupy places where malaria prevails carry the allele that underlies the sickle cell trait [126]. This genetic variation is therefore thought to increase successful survival and also the fitness of humans that occupy places where malaria occurs.

The intricate co-evolutionary and mutualistic relationship that exists between humans and their infective gut microbiome contributes to successful survival by helping humans to reach normal development and health. Most of these bacteria are anaerobe, and their integration and subsequent collaboration with their host species can be understood as a successful survival and adaptation strategy that circumvents the oxygen-rich environment that exists outside the gastro-intestinal tract.

It has been proven that the human gut microbiome not only aids in digestion, but also actively contributes to the morphology of the intestinal tract, and the human microbiome helps fend off less beneficial bacteria. The human gut microbiome has even been implicated to affect the brain and the central nervous system, where it is said to modulate neurotransmitters and to affect anxiety disorders. Diseases correlated with the composition of the human gut microbiome include affective disorders, multiple sclerosis, Parkinson's disease, fibromyalgia, chronic pain syndrome, irritable bowel syndrome, and obesity [127].

\subsubsection{Hybridization}

The genetic variation acquired through hybridization can be argued to disable genetic fatigue that can lead to extinction [128], and it provides a way to enter and colonize the genome of adjacent species [85]. Hybridization might even be considered "genetic rescue" [128] when rapid habitat changes threaten survival, and acquisition of the genes of adjacent species leads to rapid adaptation to new environmental conditions and thus successful habitat expansion. An example is found in the ancient and ongoing crossings between brown/grizzly bears and polar bears. Previous crossings between the different bear species enabled the polar bears to acquire sufficient genetic diversity, and current crossings might be a way to enable the polar bear to adapt to warmer environments [106].

\subsection{Heredity (Reproduction, Gene Flow) and Fitness}

All types of reticulate associations can impact heredity, reproduction, gene flow, and fitness.

\subsubsection{Symbiosis and Symbiogenesis}

Symbiosis and symbiogenesis play an important role in heredity in two ways. Firstly, symbionts can become inherited in non-Mendelian ways, and when they are, they are transmitted in their entirety. Secondly, symbionts can also alter the reproductive cycles and reproductive success of their hosts.

Carl Correns [129], one of the re-discoverers of Mendelian hereditary laws, was also one of the first, or perhaps the second (coming in after Erwin Baur [130]), to provide proof for the existence of "cytoplasmic inheritance" in eukaryotes. Alternatively known as extra-nuclear inheritance, it emphasizes the important role played in inheritance by, amongst others, mitochondria and 
chloroplasts. These symbiotically acquired organelles, which contain their own DNA that is reminiscent of their bacterial origin, are transmitted via the mother. Thus, while in humans, for example, the DNA in the nucleus of the zygote stems from the recombination of parental genes present in the nucleus of the female ovum and male sperm, the DNA present in the mitochondria was acquired exclusively from the mother because the ovum already contains mitochondria in its cytoplasm. Male sperm cells also contain a mitochondrion in their tails, but only the sperm's head makes it into the ovum upon fertilization.

Azolla are green or red heterosporic ferns that float on the surface of water [46,131]. In their leaf cavities, Azolla houses Anabaena azollae which are nitrogen-fixing filamentous cyanobacteria. The Anabaena azollae bacteria can fix huge amounts of nitrogen from the atmosphere, and this provides nutrition to the fern that cannot produce it by itself, which enables the fern to rapidly expand across the water. The bacteria are always present in the various life cycles of the fern, either in the leaf cavities or in the chambers of the sexual structures called sporocarps. Based on microscopic observations, it is assumed that the bacteria are vertically transmitted to the Azolla offspring via the sporocarps before fertilization. Azolla also houses several bacterial communities of the genus Arthrobacter, Corynebacterium, and Agrobacterium that are also suspected of vertical transmission in this way.

Table 2. Wolbachia impact on host reproduction and fitness.

\begin{tabular}{|c|c|}
\hline $\begin{array}{l}\text { Cytoplasmic } \\
\text { incompatibility }\end{array}$ & $\begin{array}{l}\text { In fruit flies (Drosophila paulistorum, D. recens, D. subquinaria, and D. melanogaster), } \\
\text { parasitoid wasps (Nasonia giraulti), and two-spotted spider mites (Tetranychus urticae) [132], } \\
\text { the sperm of infected males is altered in such a way that the males can only mate } \\
\text { successfully with females infected with the same Wolbachia strain; when the infected males } \\
\text { fertilize eggs from uninfected females or females infected with another strain, the embryos } \\
\text { die }[133,134] \text {. }\end{array}$ \\
\hline $\begin{array}{l}\text { Feminization of } \\
\text { genetic males }\end{array}$ & $\begin{array}{c}\text { In pill bugs (Armadallidium vulgare), butterflies (Eurema hecabe), and leafhoppers } \\
\text { (Zyginidia pullula) [132], Wolbachia can make infected males develop as } \\
\text { (pseudo)females [135]. }\end{array}$ \\
\hline Male killing & $\begin{array}{c}\text { In pill bugs (Armadallidium vulgare) and butterflies (Acraea encedon and } \\
\text { Hypolimnas bolina) [132], Wolbachia can kill infected males at larval or embryonic stage } \\
\text { before they reach sexual maturity }[136,137] \text {. }\end{array}$ \\
\hline Parthenogenesis & $\begin{array}{l}\text { In mealybug parasites (Apoanagyrus diversicornis), parasitoid wasps (Asobara japonica, } \\
\text { Leptopilina clavipes, Muscidifurax uniraptor, Neochrysocharis formosa, and Galeopsomyia fausta), } \\
\text { and thrips (Franklinothrips vespiformis) [132], Wolbachia alter the sexual reproductive organs } \\
\text { and they disable male fertilization of the eggs, resulting in the unfertilized eggs developing } \\
\text { as females [138]. }\end{array}$ \\
\hline
\end{tabular}

Facultative symbiotic relations also significantly impact reproduction and fitness of both the host and the symbiont. Wolbachia are bacteria that infect a variety of worms and insects including flies, mosquitos, wasps, moths, and butterflies. Wolbachia bacteria are mostly acquired during ontogeny where they infect somatic cells, but they can also make their way to the ovaries and the cytoplasm of their female host eggs, and the testes but not the sperm cells of their male hosts. Infected female insect eggs can thus transmit the Wolbachia to their offspring, making it another example of cytoplasmic inheritance [139]. However, Wolbachia can do more than that. It can impact reproduction and host fitness by inducing cytoplasmic incompatibility, feminization of genetic males, male killing, and parthenogenesis (Table 2) [140-142]. Such Wolbachia-induced reproductive isolation can result in "speciation by symbiosis" [132]. We return to this in Section 3.5.

\subsubsection{Lateral Gene Transfer}

The genomes of both prokaryotes and eukaryotes demonstrate the presence of numerous foreign DNA elements that got there either through lateral gene transfer or infective heredity, or through hybridization. These genetic studies furthermore show that many of these acquisitions are not only stable but highly conserved over the course of evolution [143]. 


\subsubsection{Infective Heredity}

In unicellular eukaryotes, the line between cytoplasmic inheritance and infective heredity of symbionts is often a fine one, and a line that can also easily be crossed. A classic and well-documented laboratory example includes the cultures of ciliated protozoa called Paramecium aurelia. The paramecia are distinguished into killer or sensitive types after Sonneborn [144], who first noticed that besides dividing by fission, the members belonging to these different types can complete conjugation (a process that takes many hours), while members of the same type cannot and instead separate before completing conjugation. Nonetheless, conjugation is followed by death of the sensitive strain induced by toxin particles released into the surroundings by the killer strains and absorbed by the sensitive strain. The toxin responsible for this mate-killing is produced by refractile bodies ( $\mathrm{R}$ bodies) present in what are called kappa killers that reside in large and varying numbers in the cytoplasm of the killer paramecia.

Electron-microscopy research by Preer, Preer, and Jurand [145] demonstrated that the Kappa killers are in fact Gram-negative endosymbiotic bacteria (Caedibacter taeniospiralis), and the authors pointed out the close resemble the $\mathrm{R}$ bodies have with trichocytes and with defective phages when unrolled. Beyond the kappa killers, the paramecia carry many more endosymbiotic particles, including the non-killer endosymbionts nu (Caedibacter falsus) and pi that are descendants from kappa by mutation, and the related mate-killers gamma (Caedibacter minutus) and mu (Caedibacter conjugatus), lambda (Lyticum flagellatum) and sigma (Lyticum sinuosum), delta (Tectobacter vulgaris), and tau (related to $\mathrm{mu}$ and nu) [145] (pp. 152-158). When harboring these endosymbiotic killer-particles, paramecia are bestowed with resistance to their specific mate-killer techniques, but only for as long as the endosymbionts are present because they can be lost. Infection with one endosymbiont does not give immunity to the toxin produced by another. Instead, killers kill killers.

All these endosymbionts reside in the cytoplasm where they are subject of cytoplasmic inheritance/infection, but the facultative endosymbionts also depend upon the genetic apparatus of the paramecia that carry "maintenance genes" enabling proper functioning of the endosymbionts [145] (p. 146). In addition, the paramecia's macronucleus contains the alpha endosymbiont stemming from Holospora caryophila (previously called Cytophaga caryophila) that is also a mate-killer when found in combination with kappa [145].

In multicellular eukaryotes, symbionts facilitate female eukaryotes, including humans [146], to have successful pregnancies that are carried to full term. Even the human placenta appears to house a specific microbiome [147] that helps fetal development [148]. In the context of infective heredity, during lactation of offspring, numerous beneficial microbes as well as antibodies against pathogens are passed on that strengthen the offspring's immunity and that enables offspring to survive successfully and to adapt to their environmental surroundings (a process first described by Ehrlich [149], but see also $[150,151])$. Endogenous retroviruses have moreover had a significant impact on vertebrate reproduction by playing a physiological role in the formation of the mammalian placenta, including the human placenta $[152,153]$.

\subsubsection{Hybridization}

Hybridization can put a genetic load on the hybrid organisms that decreases their fitness. However, based on results from cross-pollination experiments with, amongst others, pees, tomato, and tobacco plants, Darwin [154] already reported that hybridization can also elevate fitness by increasing variation. As such, it can be contrasted from inbreeding that decreases fitness. This is because inbreeding tends to bring deleterious traits to the surface that weakens the species.

Hybridization often makes offspring bigger and stronger than their parental species. The phenomenon was called hybrid vigor or heterosis by Shull [155] based on results he obtained from artificial breeding experiments with maize (Zea mays). Lines of maize that were inbred to near homozygosity grew less while hybrids between these lines instantly reversed the process and yielded more harvest than their randomly mated (open-pollinated) parental species. The first-generation hybrids had a smaller seed 
production, but crossings between different strains of hybrids with a technique known as four-way crossing resulted in similar numbers of seed production.

The potential maize hybrids have over their open-pollinated parental species revolutionized the American corn-based food industry in what has been considered "one of genetics' greatest triumphs" [156]. Hybrid corn is more uniform, more resistant to drought, can adapt to different habitats, and enables a lengthening of the growing season. Similar enhancement techniques were later also adopted for rice cultivation (Oryza sativa) in China, India, and Indonesia that has since witnessed a similar revolution [157].

While hybrid vigor and heterosis are terms that are often used interchangeably, Chen [157] pointed out that hybrid vigor "is evolutionarily defined", as hybrid heterozygotes having a higher fitness than their homozygotic parental species, while heterosis more generally "refers to superior levels of biomass, stature, growth rate, and/or fertility in the hybrid offspring than in the parents".

At a genetic level, the phenomenon can be explained by hybridization giving rise to polyploid organisms whose cells contain multiple chromosomal sets [157]. Beyond maize, other examples of polyploid hybrids are found in seed-producing flowering plants (angiosperms), or wheat which is an allopolyploid hybrid because it contains chromosomal sets of different species. In general, the level of heterosis increases proportionally to the genetic distance that exists between the parental species. As further discussed in Section 3.5., polyploidy can also facilitate speciation.

Beyond genetics, hybrid fitness depends not only upon similarity in genotypes but also upon environmental conditions such as the state of natural habitats as well as seed viability in early life-history stages. The interplay among genes, environment, and development on adaptive trait introgression can be studied experimentally [128].

An example is the Louisiana Irises studied by Arnold et al. [106]. The scholars examined hybrids of Iris brevicaulis and Iris fulva. Both species often occupy the same regions, with the former generally growing in a bit more elevated and therefore dryer areas of land than the latter that grow in lower and wetter areas. Hybridization experiments were conducted between the species that also allowed for backcrossing with both of the parental species, and both were grown in a drier greenhouse and in a wetter common garden.

In the drier greenhouse, as to be suspected, backcrossed genotypes toward Iris brevicaulis survived at higher rate than backcrosses toward Iris fulva. Three quantitative trait loci (DNA sections associated with phenotypic traits) that introgressed from Iris brevicaulis to Iris fulva increased the latter's survival, which is consistent with a model of adaptive trait introgression.

The same backcrossed populations were grown in a common garden that during the experiment became flooded more than is usual. Under these extreme conditions, only a third of the original Iris fulva survived as well as $10 \%$ of the backcrosses toward Iris fulva. None of the Iris brevicaulis survived, and those that did from the backcrosses contained more alleles from Iris fulva. Thus, those Iris brevicaulis that survived the wetland survived because they carried genes that they acquired through introgressive hybridization with Iris fulva that is adapted to moderate wetlands [106].

\subsection{Evolutionary Constraints and Affordances}

All types of reticulate associations can provide constraints and affordances to how reticulating organisms evolve.

\subsubsection{Symbiosis and Symbiogenesis}

Waddington [158] defined canalization as the robustness or persistence of a phenotype despite genetic or environmental alterations. Canalization provides a constraint or barrier imposed by phenotypic development (that is compared to canals in an epigenetic landscape) on environmental selection, because minor variations in external selection pressures are ignored in favor of the establishment of stable developmental pathways. At micro- and meso-scale, canalization can lead to genetic assimilation in which case the genotype is "set" to bring forth the "desired" phenotype. 
Such evolutionary developmental constraints are also investigated by macroevolutionary-oriented scholars because it can help explain stasis, the apparent lack of evolutionary change over long periods of geological time despite environmental or genetic changes [159].

Both concepts of canalization and stasis can easily be extended toward reticulate evolution. Over the course of generations certain species such as the bobtail squid integrate only those symbionts beneficial to them. In general, holobionts often maintain phenotypic integrity despite constant alterations in what Rosenberg [52,160] calls the hologenome that sums up the genes from its symbionts.

Reticulate evolution also shapes the (a)biotic environment by both constraining and providing affordances on how reticulately associating biological individuals will evolve. These constraints and affordances surpass an individual's genetic potential, and reticulation plays an active role in bringing about either stasis or evolution.

Endo-symbiogenesis was an integral part of the events that generated eukaryotic ancestors. Eukaryotes have some fundamental features that derive from Bacteria (oxidative and general metabolism, membrane composition) and others that derive from Archaea (replication, transcription, protein synthesis, and cytomechanics). Bacterial endo-symbiogenesis and their subsequent evolution into organelles has significantly narrowed the future directions that eukaryotic evolution can take. Leaving aside the anaerobic eukaryotes which harbor mitochondrion-derived organelles known as hydrogenosomes and mitosomes, most of the eukaryotic descendants are living either aerobe or aerobe-photosynthetic lifestyles, which is an affordance and a constraint brought forth by the mitochondria and chloroplasts that reside inside them. Changing to a different life-mode, such as an anaerobic one, would imply a significant evolutionary re-tinkering. The evolutionary development of organelles out of acquired bacteria by symbiogenesis has therefore rightfully been characterized as one of the major transitions [161].

Applying an evolutionary epistemological jargon [162-165], it is safe to say that human beings today come with a biologically-evolved expectation to live in an oxygen-rich environment, and their gastro-intestinal tract as well as entire bodies expect to become populated with microbial communities, some of which will enable the digestion of food provided by the environments, others will be harmful for which the human body is or will be able to develop immunity. Equally, Hawaiian bobtail squids [117] come with a biochemically programmed expectation to find luminescent bacteria that will colonize their light organs, as well as induce post-translational epigenetic and morphological changes to it. Failure to acquire these symbionts will significantly decrease the squid's chances of survival and reproduction. Symbioses that are ontogenetically repeated over generations, or that become obligate for the host, its symbionts, or both, provide evolutionary constraints and affordances to all parties involved, as well as to their future generations.

Obligate intracellular endosymbionts are geographically and thus also sexually cut off from their free living conspecifics. As such they are deprived from any possible lateral or vertical gene flow with their conspecifics living outside their host. A correlating event relevant for our investigation into constraints is that these obligate intracellular symbionts initially undergo significant gene loss, and subsequently a strict and conserved co-evolutionary process takes shape between the host and the symbiont. Feldhaar and Gross [166], for example, noted that:

"The complete isolation of these bacteria from other microbes as a result of their permanent intracellular lifestyle means a lack of horizontal gene transfer, resulting in a strict co-evolution of the symbionts with their hosts. In addition, a constant supply of metabolites from the host and a relatively stable environment relax selection pressure on the maintenance of many, mainly metabolic, genes. This has had dramatic consequences for the genome structure of the bacteriocyte endosymbionts. In general, these genomes are characterized by a strong AT bias (more than 70\%), extremely reduced genome sizes of 160-800 kb, a complete stasis of genome structure, an extreme reduction in the numbers of transcriptional regulators, and recombination and DNA repair factors, and high mutation rates." 
In short, symbiotic relations introduce co-evolutionary relationships between the host and the symbiont, and such reciprocal fine-tuning puts enormous constraints on the evolutionary directions either of the formerly independent partners can take.

\subsubsection{Lateral Gene Transfer}

As with endosymbiosis, case studies exist [167-169] that prove that genes acquired by lateral gene transfer go through a phase of gene loss, after which the remaining ones become highly conserved. After initial sorting, acquired and conserved genes are protected against mutation, loss, or substitution, and this is probably because they provide benefits to the holobiont.

\subsubsection{Infective Heredity}

Infectious diseases can severely impact the variability, life course, and fitness of both hosts and pathogens, and this can in turn influence the future course of evolution. Infections with Wolbachia, for example, disable and constrain Aedes aegypti mosquitos from being infected with Dengue and Zika (both of the yellow fever and Flaviviridae family), Chikungunya (from the Togaviridae family) and Plasmodium pathogens [170]. Artificial infection of these mosquitos with Wolbachia would therefore also constrain not only infections in mosquitos but also human infections with the pathogens. Likewise, infection with one bacteriophage such as lambda can protect $E$. coli bacteria to become infected with similar bacteriophages.

In humans, pathogen-induced diseases such as leprosy (Mycobacterium leprae) or the plague (Yersinia pestis) bring forth phenotypic changes that are known to have impacted group-level responses that beyond introducing social stigmas have resulted in the introduction of quarantining strategies (isolating infected individuals on islands, for example) and sociopolitical laws that prevent any form of contact, including of a sexual kind, with diseased individuals.

\subsubsection{Hybridization}

Hybridization can bring forth evolutionary constraints by introducing reproductive barriers due to chromosomal incompatibility, a failure of the organisms to recognize one another as potential mates, or a failure of the associating symbionts to recognize their hosts and to facilitate reproduction (in the case of flowering plants and their pollinators, for example). At the same time, hybridization enables invasion of adjacent gene pools as well as new ecological niches, and the introduction of a new genetic unity through hybridization contributes to the formation of a new genealogical lineage.

\subsection{Speciation}

All types of reticulate associations can impact speciation.

\subsubsection{Symbiosis and Symbiogenesis}

All types of reticulate evolution imply a form a gene flow between distinct organisms and species. Because symbiosis affects adaptation, fitness, reproduction, and ecological systems, and because all the latter can influence speciation, symbiosis can affect speciation. Many symbionts influence stages in the reproductive cycle of their hosts, thereby either inducing or disabling sexual compatibility of their host with conspecifics. Symbiosis can tamper with the female/male ratios of host populations, it can influence mate choice, determine the sex of the host, and thereby introduce reproductive barriers that can lead to reproductive isolation. Such reproductive isolation is considered a basic means whereby species diverge and speciate over time [171]. Symbionts can also influence group composition and size, and this may cause population bottlenecks which are also well-recognized features of speciation and extinction [140,172-175].

A useful distinction was made by Shropshire and Bordenstein [132] who distinguished between prezygotic (occurring before fertilization) and postzygotic (occurring after fertilization) mechanisms, 
whereby symbionts can introduce reproductive isolation. Postzygotic mechanisms include hybrid sterility or unviability. Symbiont-induced, prezygotic reproductive isolation can occur in two modes:

"Broad-sense symbiont-induced reproductive isolation refers to divergence in host genes that result in a reproductive barrier because of selection on the host to accommodate microorganisms. In this case, loss or alteration of the symbiont does not have an impact on the capacity to interbreed; instead, host genetic divergence and reproductive isolation evolve in response to microbial symbiosis and cause isolation regardless of whether the hosts are germfree or not. Conversely, narrow-sense symbiont-induced reproductive isolation occurs when host-microbe or microbe-microbe associations result in a reproductive barrier, namely, one that can be ameliorated or removed via elimination of the microbes. Therefore, narrow-sense isolation can be experimentally validated if it is reversible under microbe-free rearing conditions and inducible with the reintroduction of microbes. Isolation barriers that require host and microbial components underpin hologenomic speciation" [132] (p. 2).

An example of narrow-sense symbiont-induced reproductive isolation involves the impact of the microbiome on mate preference in fruit flies. Dodd [176] was one of the first to suggest that distinct diets of fruit flies (Drosophila pseudoobscura) influence mate choice and cause for reproductive barriers. A team from the Rosenberg lab [177] later repeated the experiments with Drosophila melanogaster and confirmed the results, additionally demonstrating that the altered diet influenced the composition of the gut microbiome of the flies, and that it was thus the microbiome that induced the reproductive barriers. Removal of the different food types that had led to the pheromone-based disinterest resulted in renewed sexual interest.

Humans produce two kinds of sweat coming from two different glands in their armpits. One is associated with heat responses, the other with stress and emotional responses including sexual responses. Froebe et al. [178] demonstrated that the sweat produced by the second glands in response to emotional stress are initially sterile and odorless, and they receive their particular odor through the work of microbiota (Corynebacterial strains). The microbial communities contribute to odor production in humans that associate with sex and possibly attractiveness during partner choice.

Our gut microbiome is currently thought to influence overall body odor [179], weight [180-183], and even personality traits [184-186]. All the latter are known to influence partner choice in humans, and it can alter the associated behaviors involved in recognizing and in convincing a potential mate to engage in sexual reproduction. This ontogenetically acquired individual variation can have long-lasting effects on future generations, by providing directionality (by causing bottlenecks, for example) to the evolution of both the host and its symbionts.

Beyond partner recognition and mate attractiveness, the gut microbiome can even signal group belonging [187] and social rank [188,189].

\subsubsection{Lateral Gene Transfer}

Modern Synthesis states that speciation occurs due to genetic and geographical isolation [171]. This might lead one to think that lateral gene transfer, which per definition looks at interactions, has no bearing on matters of speciation. However, an article by Papke et al. [190] demonstrates that, because lateral gene flow amongst prokaryotes is differential (prokaryotes are more easily able to exchange genes with bacterial strains close to them), it might actually contribute to overall prokaryotic diversity by causing isolating barriers to gene flow between distinct bacterial groups. Stated differently, maintaining gene flow between closely related prokaryotes facilitates homogenization of their genomes and differentiation of the latter to other prokaryotic strains. The authors furthermore demonstrated that such divergence and homogenization occur more rapidly than by mere mutation alone. A similar case is made by Nowell et al. [191] who posited that lateral gene transfer underlies diversification of bacterial lineages of Pseudomonas syringae (which are Gram-negative bacteria that cause cancerous diseases in cherries, prunes, and peaches, and their trees). 


\subsubsection{Infective Heredity}

Effects of mobile DNA or pathogen-based diseases on speciation remain formulated in theoretical and hypothetical terms. Recent studies have implicated transposable elements in disrupting the flowering time and photoperiod of plants such as Arabidopsis, maize, and rice, and they have been associated with hybrid defects which might be cause for reproductive barriers that can lead to speciation [192]. Transposable elements have also been implicated in causing rapid adaptation to new environmental habitats [193].

Lin et al. [194] emphasized the role of cross-species transmission of viral pathogens in bringing forth new viral strains. Examples include Hanta viruses that are spread by rodents and that can infect humans; the two main Human Immunodeficiency Viruses (HIV1 and HIV2) that are responsible for AIDS and that stem from SIV (Simian Immunodeficiency Virus) viruses found in chimpanzees (SIVcpz) and sooty mangabeys (SIVsmm); and avian (HPA1) and swine influenza viruses (SIV or S-OIV strains). These viruses have often been long part of the viriome of their host species where they cause harmless infections. However, when such a virus is able to transmit to other species, it demonstrates rapid speciation from old strains and a virulence that often takes epidemic and pandemic proportions.

When forecasting the warning, Lin et al. [194] also already pointed toward the group of coronaviruses [195] that beyond SARS-CoV responsible for SARS (Severe Acute Respiratory Syndrome) and that was transmitted via masked palm civets $[196,197]$, today also include MERS-Cov2 responsible for MERS (Middle East Respiratory Syndrome) transmitted by camels [198], and the recent COVID-19 (SARS-Cov-2) coronavirus that in humans also brings forth severe respiratory syndromes and that probably became transmitted via pangolins [199]. While transmitted via these organisms to humans, all three coronaviruses are thought to find their origin in bats and their SARS-like coronaviruses (SL-CoVs) [200].

Originating in bats and having infected the human species via the intermediary species, the COVID-19 virus is now able to rapidly multiply and diversify into several mutated strains within the human species (https://nextstrain.org/ncov/global). From November 2019 to January 2020, the SARS-Cov-2 virus was able to spread from Wuhan, China to the rest of the world. The human species is therefore demonstrating how one single species can enable the worldwide spread of a single virus and its mutated strains.

At the same time, due to the rise of group- and species-level awareness of the virus, which is in turn the result of rapid individual to group-level transmission of culturally-evolved scientific knowledge, the human species is also constraining the virus by species-wide and globally-implemented quarantining techniques. In sum, the human species is a drastic example of how pathogenic outbreak and spread can be enabled and contained as well as how it imposes barriers to gene flow of both host and pathogen, as well as rapid speciation of the pathogen.

\subsubsection{Hybridization}

Hybrid speciation, defined by Arnold [201] as "the formation of evolutionarily independent lineages from genetic exchange events between divergent taxa", is today well documented in both plant $[86,202]$ and animal (including human) species [106]. The numerous reported cases demonstrate that geographic or reproductive isolation are not necessarily amongst the requirements for speciation to occur.

Hybridization often leads to polyploidy which is a common state of the cells of many flowering plants (angiosperms). As discussed in Section 3.3., polyploidy is a known source of species diversity $[157,203,204]$. Diploidy means that the organism carries in its cells the paired chromosomes from its parents, one from each. Polyploidy means that the cells carry more than two homologous sets of chromosomes. These extra chromosomal sets either result from whole genome duplication or from nondisjunction of the chromosomes during meiosis or mitosis occurring within the same species (autopolyploidy). Conversely, the extra chromosomes result from hybridization between different 
species (allopolyploidy) [205] (p. 6991). When the hybrid offspring is sterile, it can overcome this sterility by undergoing whole genome duplication during rapid speciation episodes.

That the diversity introduced by polyploidy can underlie speciation was first reported by Stebbins [17] (p. 56) who noted that:

"... the fertility of a plant is enormously affected by polyploidy. If the original plant is a fertile species, the polyploid derivative will be partially sterile, due to the formation of multivalent associations of chromosomes and their occasional irregular segregation. If, on the other hand, the diploid plant is a sterile hybrid, the polyploid produced from it is generally fully fertile. This last fact is the basis of the principle of allopolyploidy or amphidiploidy, the importance of which in the development of plant species cannot be stressed too strongly. Equally important is the well-known fact that tetraploids are not only difficult or impossible to cross with their diploid progenitors, but also produce practically sterile triploid $F_{1}$ hybrids when crossed with them. This brings us to the all-important fact, now so well known that I need not cite the numerous examples of it, that by means of chromosome doubling or polyploidy a sterile hybrid can produce directly a fertile, constant species. On this fact is based the chief classification of polyploids into autopolyploid and allopolyploid types."

Stebbins studied the process in plant species belonging to Crepis acuminate (tapertip hawksbeard) of the Aster family. These flowering plants can be either diploid or polyploid. When auto- and allopolyploid types of Hawksbeard cross, the second-generation of hybrids is often unable to reproduce sexually and instead they go on to self-perpetuate. This process is known as apomixis: the sexual reproduction mode of the parental species is replaced by asexual reproduction. As such, these flowering plants can continue to diversify asexually into numerous subspecies making way for " ... a complex network of interrelated forms, which defies classification according to the usual concepts of the species". In collaboration with Babcock, Stebbins [17] (p. 60) called this a "polyploid complex" and he noted that:

“... the gaps between species no longer exist or are at least very much smaller and harder to recognize. Polyploidy, therefore, tends to break down genetic barriers and to permit exchanges of genes between genetic systems that in the diploid condition are completely isolated from each other."

Following Turrill [206], Huxley [207] (pp. 352-353) referred to these second-generation self-perpetuating hybrids as bringing forth "reticulate evolution". For Stebbins [17] (p. 64), in comparison with a group of diploid species, a polyploid complex was a "closed system" because "it can produce endless new species, but these are all or nearly all new combinations of the same supply of genetic material; they are new variations on an old theme".

Nonetheless, both Stebbins [87] and Anderson [16] emphasized how hybridization has contributed to a maximalization of genetic variation of the flowering plants, and how this in turn has enabled the hawksbeard to invade new and diverse ecological niches. Both increase survival.

Hybridization can lead to speciation without an increase in ploidy, in which case it is called homoploid hybrid speciation or recombinational speciation. The process is considered rarer but it is also less easy to detect [88].

\subsection{Extinction}

All types of reticulate associations can influence extinction.

\subsubsection{Symbiosis and Symbiogenesis}

Extinction can be considered a natural outcome of successful species that just because they are able to survive and adapt to distinct environments as well as to reproduce, will naturally become genetically divergent from their parental stock up to the point that they have evolved into a new species. Additional factors that contribute to species extinction are inter- and intra-species competition for shared resources [208] as well as abiotic factors can influence extinction events [209]. 
Because both the host and its symbionts come to significantly rely on one another to provide nutrients that neither can provide on their own to produce life-essential metabolic functions, or to enable reproduction, symbiotic relations can easily explain not only extinction but also co-extinction events. If bees and wasps were to go extinct, for example, it is highly likely that numerous symbiont-dependent flowers will fail in rapidly evolving new means to pollinate.

Parasitic symbionts can have detrimental effects on the life course of their host. Min and Benzer [210] (p. 10792) reported on a Wolbachia strain found in Drosophila melanogaster that negatively impacts the normal life span of the flies by inducing "widespread degeneration of tissues, including brain, retina, and muscle, culminating in early death". One can also ask, and with good reason, whether a Wolbachia-infected female host is still to be understood as a member of her species, even though she shares the same nuclear genes. Brucker and Bordenstein [172], for example, and continuing along the lines set forth by Margulis' symbiogenetic species concept, launched the new field of symbio-phylogenetics, which questions current species concepts in favor of a symbiotic one, thereby grouping the individuals that share the same microbionts into new classes.

At present, one can argue that it is merely a matter of epistemic taste whether one describes the "parable of the daisy world" [211] in terms of the Gaia hypothesis, co-evolution and the red queen hypothesis [212], or symbiosis. The fact is that beyond predator-prey relations, host-symbiont interactions result in biased or directional reproductive strategies [213]. These can contribute to overall stasis and impose evolutionary constraints, and lead to co-evolution, co-speciation, and co-extinction.

\subsubsection{Lateral Gene Transfer}

Lateral gene transfer can bring back genes from the dead through processes of transformation and genomes are filled with genes of which the host (species) did not survive [71]. Lateral gene transfer might therefore be an adaptive response to extinction, by providing a lifeline to those abandoning a sinking ship, so to speak.

A thorough search of the relevant literature yielded no available data on how lateral gene transfer contributes to extinction of specific strains. In general, evidence for bacterial extinction is also rare (see [214,215]). Nonetheless, lateral gene transfer not only makes barriers between bacterial strains or species more fluid, it also increases exclusion between groups by enabling genetic unity within groups. This might count as a factor for intergroup competition that can lead to one group outcompeting and thereby eliminating another. The same goes for the natural barriers that appear to exist for gene flow from pro- to eukaryotes.

\subsubsection{Infective Heredity}

It was already discussed how disease can impact reproduction and successful survival. Parasitic symbiotic relations that cause disease and that are detrimental to one of the symbiotic partners, and synnecrosis which is a rare symbiotic relation that is detrimental to both partners, can also lead to co-extinction of both the host and the symbiont. Examples of these are lethal diseases that affect large populations, making both the host and the pathogen die out. Human history is plagued with numerous pandemics such as the plague and HIV [61]. According to the World Health Organization [216], HIV has so far claimed over 32 million lives, 75 million people have been infected with the virus, and 37.9 million are currently living with HIV [217]. The Spanish flu killed around 5 million people. Other examples are the already at length discussed coronavirus infections responsible for SARS or COVID-19 respiratory disease. On 13 June 2020, the World Health Organization reported on 7,553,182 million confirmed cases of COVID-19 infection in humans, and a total of 423,349 deaths (https://www.who.int/docs/default-source/coronaviruse/situation-reports/20200613covid-19-sitrep-145.pdf?sfvrsn=bb7c1dc9_2). Conservationists can easily provide a list of endangered species that have a much smaller head count.

In a context of endogenous retroviruses, Ryan $[61,218]$ introduced the term "plague culling", by which he emphasized that diseases have the potential to cause bottlenecks, and especially pandemics 
have the potential to wipe out entire species. Retroviruses are able to infect the germline. Even if they merely infect somatic cells, bacteria and viruses can be "carried" by populations, species, and higher taxa where members of each generation anew become horizontally infected. Such viruses moreover jump between species, and evolve not only at an intraspecific level but also at an interspecific level. As such, diseases can threaten successful survival and reproduction and contribute to extinction.

\subsubsection{Hybridization}

Hybridization can lead to a loss of biodiversity. Introgressive hybridization leads to anagenesis of the parental species that evolves itself out of existence or that undergoes significant changes to the genome. When it leads to cladogenesis due to sexual incompatibility between hybrids and the parental species, the hybrid progeny can prove to be more fit and outcompete its parental species.

Studies also demonstrate that the introduction of nonindigenous fauna and flora can results in extinction of native species, especially when rare local species hybridize with the new inhabitants and the result is sterility [219]. It is already explained above how chromosomal doublings contribute to fitness (Section 3.3) and speciation (Section 3.5). However, chromosomal doublings can also bring forth sterility and lethality. In this regard, Maheshwari and Barbash [220] (p. 336) note that:

"If two hybridizing species have different karyotypes, then hybrids may suffer from meiotic defects or produce gametes that are aneuploid, and thus be sterile... Polyploid hybrids are frequently sterile and are common among plants ... Chromosomal inversions have also been widely implicated in causing hybrid sterility."

In animals, hybridization can also cause for a rupture in recognizing one another as potential mates.

\section{Concluding Remarks and Future Prospects}

The Darwinian principles were formulated within Neo-Darwinian schools of thought to prove that evolution occurs, and that it occurs by means of natural selection. In this review, it is tested how "Darwinian" these principles really are, by demonstrating that they also underlie reticulate evolution. The following two important conclusions can now be reached.

1. While most certainly indicative of evolution, the principles of variation, adaptation, heredity and fitness, constraints and affordances, speciation, and extinction are not exclusively "Darwinian". Rather, all can occur by means of reticulate evolution. For these reasons, the phenomena should be understood as universal principles of evolution that enable a further objectification of evolutionary research, one also applicable for testing other mechanisms and processes of evolution, such as drift for example (Section 4.1).

2. The principles have often been understood as "properties" or "traits" that are somehow carried by genes, organisms, or species, thereby implying that these are qualities or characteristics inherent to these entities or otherwise possessed by these entities. However, what this review demonstrates is that the principles are exherent to the entities that demonstrate them, because they result from horizontal and reticulate interactions between different units, levels, mechanisms, and processes across evolutionary hierarchies. The principles are "carried" by the interactions that exist amongst organisms belonging to different taxa, and these interactions too are diverse and changeable over time and space, because these too evolve (Section 4.2).

These points are discussed one by one.

\subsection{Universalizing the Principles}

In so far as all types of reticulate evolution impact variation, adaptation, heredity and fitness, constraints and affordances, speciation, and extinction, it is misleading to call these phenomena "Darwinian" principles. Instead, it is hereby suggested to call them "evolutionary" principles that are 
shared by numerous mechanisms and processes. The key principles can thus be both neutralized and universalized into scientific jargon that underlies an integrative and pluralistic approach to the study of evolution.

Genealogical hierarchies are basically built up of a Linnaean taxonomy turned evolutionary [221]. Previously, such taxonomies were based upon "essential" and "accidental" features, and it was assumed that "essential features" are species-specific, i.e. "unique" and "intrinsic" to that species. Darwin's major breakthrough was that he argued that all species are connected through what he called "the bloodline" (the descent or germline) [222], which turned classification keys into "pedigrees" and "trees of life" that demonstrate genealogical descent. What followed were assumptions of single and common descent with modification, as well as ideas that genetic, morphological, behavioral, and reproductive features were "the property" of the individual or the species, and that these eventually determined successful survival and speciation or that they induced extinction.

Reticulate evolution necessitates a revision of conventional (Neo-)Darwinian views on what counts as "species-specific" or "organism-specific" "properties" or "traits". The universal evolutionary principles cannot become reduced either to underlying gene pools, or to factors in the abiotic environment. These phenomena are instead brought forth by numerous organisms that interact reticulately amongst themselves and with the abiotic environment, and such varying "properties" are "carried" and made possible by the various interactions there exist between different species.

\subsection{The Universal Evolutionary Principles as Exherent Common Goods Brought Forth by Interactions}

When the universal evolutionary principles are used as objective markers and tested against reticulate evolution theories, it is found that reticulate evolution impacts all these phenomena and this demonstrates that none of these evolutionary principles are gene-, organism-, or species-specific traits, or phenomena induced by the environment. Instead, all emerge from interactions.

\subsubsection{Variation}

Variation cannot be reduced to a mere genetic level and it is not merely the result of random genetic mutations conceived of as copying errors. Variation is also not a property of one organism, one population, or one species. Instead, it is the outcome of interactions among genes, organisms, and species. As Shapiro [15,42] demonstrated, living systems demonstrate remarkable "natural genetic engineering" or self-regulating and even cognitive capacities from the molecular level onward, and our genomes are not read-only codes, but they can be rewritten as a result of organismal, multi-species, and ecological interactions. Shapiro [15] wrote (pp. 24-25):
"In formulating 21st century evolutionary principles, it is important to incorporate certain major empirical discoveries in the biological sciences: 1. All extant organisms have sophisticated molecular systems for monitoring external and internal conditions, which they use cognitively to adjust their physiologies, correct errors, and repair damage to ensure survival, growth, and reproduction. 2. All extant organisms can actively modify their read-write DNA genomes in response to ecological disruption or biological challenge. 3. Many hereditary changes result from biosphere interactions ... "

\subsubsection{Successful Survival and Adaptation}

The Neo-Darwinian Synthesis understands survival as the outcome of adaptation to the environment. Adaptation is measured by an organism's fitness which means that adaptation is measured by genes, whether or not they are thrown back into the imaginary gene pool. If the organism is not adapted, the environment is assumed to disable the organism to survive until reproduction (i.e., natural selection due to a struggle for existence), or, if it is, it is assumed to produce less offspring (i.e., sexual selection in the battle between the sexes).

However, successful survival can neither be reduced to the organism's individual genes, nor be understood as the sole outcome of environmental or sexual selection. Organismal survival instead 
depends upon the ability to create new environmental niches, which is something that often occurs in symbiotic association with other organisms belonging to a variety of species, sometimes up to the point that holobionts are formed that are both new biological individuals as well as new habitable zones of life. In a similar context, Bapteste and Huneman [20] discussed co-constructed traits; Vigliotti et al. [223] introduced the notion of an externalized gut metagenome; and Borges [224] understood host-symbiont relations to result in co-niche construction. Gontier [165] understood symbiosis and niche construction to be foundational for spatiotemporally-bounded bioreality formation. Adaptation assumes the existence of an unchanging external environment. Instead, as shared traits brought forth by numerous organisms that interact symbiotically with one another, survival and niche construction result not in adaptation to an external world but to a re/construction of a new reality.

\subsubsection{Heredity, Reproduction, Gene Flow, and Fitness}

Overall gene flow, organismal reproduction, and fitness depends not merely on an organism's physiology or adaptiveness toward an environment, but is also influenced positively and negatively by symbiotic organisms as well as by gene carrying agents that engage in lateral gene transfer. Lateral gene transfer requires a rethink of heredity. No longer does it solely refer to intergenerational transmission of genes through the germ line. Rather, organisms can exchange genes with multiple individuals throughout their lifetime, and this can bear immediate consequences for the individual and its progeny.

Heredity can also not be reduced to genes. Bacteria and Archaea continue to make up the majority of the biomass, and they are asexual beings that multiply through cell division. When that occurs, much more than genes are transmitted. Entire cells grow and they are split into two. Reproduction and heredity can no longer be thought of as individual or genetic traits, or as brought forth by the reproductive organs of eukaryotic organisms. In sexually reproducing species, if reproduction is to increase fitness, then it requires that two members with different sex organs recognize one another as mates, that they actually mate with one another, and that offspring in turn is able to reproduce by recognizing and finding mates willing to repeat the cycle. From this perspective, it can already be concluded that sexual reproduction has never been the property of one individual, and it cannot be reduced to the workings of organismal sex organs or genes.

Reticulate evolution moreover evidences that organisms of one species can tamper with the reproductive success of other species. The human microbiome can influence our sexual attractiveness and influence mating. The Wolbachia cases reported on demonstrate that this symbiont can even induce sterility and influence the developing sex of its host. The different means of lateral gene transfer that exist amongst prokaryotes demonstrates that they too are chimeric entities. Heredity is always dependent upon a multiplicity of processes and it therefore surpasses individuals as well as the species they belong too.

\subsubsection{Evolutionary Constraints and Affordances}

Variation, survival, adaptation, heredity, reproduction, gene flow, and fitness are dependent upon the activities of plenty of organisms, and it is these kinds of interactions that impose constraints and affordances upon the course of evolution. The stable evolution of one genealogical lineage is an outcome of plenty.

\subsubsection{Speciation}

Speciation is never a species or group-specific trait merely enabled by the genetic mutations of species-specific genes, by environmental selection, or by reproductive or environmental isolation. Speciation is also caused by interactions amongst different organisms coming from different lineages, and reticulate evolution plays a significant biotic factor in this. 


\subsubsection{Extinction}

Beyond migration, predator and prey relations, and environmentally induced climate change or catastrophes, all types of reticulate evolution can contribute to the success or failure of species. Extinction is thought of either as resulting from the unsuccessful survival of individuals that make up a lineage or as the natural outcome of speciation where organisms diverge into different groups. However, extinction of one or more lineages also results from symbiotic interactions with other organisms within the biotic environment. In so far as extinction can result from abiotic environmental changes, then reticulate evolutionary processes are important players in both the construction and alteration of the abiotic environment through, e.g., the introduction of photosynthetic symbionts or through the nitrogen cycle.

Today, numerous ecological symbiologists are applying philosophical and economic "public and common goods theory" $[25,53]$ to try and make sense of the evolutionary principles brought forward by reticulately evolving organisms. Such "common goods" are properties or characteristics that are "carried" and brought forth by the reticulate interactions that require a more interactional and relational approach when they are defined. It is hereby suggested to understand these evolutionary principles as exherent and common goods.

Funding: This work was written with the financial support of FCT, the Portuguese Foundation for Science and Technology, Grant IDs SFRH/BPD/89195/2012 and DL57/2016/CP1479/CT0066 and Project IDs: UID/FIL/00678/2013, UID/FIL/00678/2019, and UIDB/00678/2020.

Acknowledgments: Cordial thanks go out to the two anonymous referees for their useful comments and suggestions.

Conflicts of Interest: The author declares no conflict of interest.

\section{References}

1. Gontier, N. The epistemological roots of the 'Darwinian' principles: Changing motives in the foundation, hardening, and loosening of the Modern Synthesis. Kairos 2020, 23, 104-134.

2. Lewontin, R. The units of selection. Annu. Rev. Ecol. Syst. 1970, 1, 1-18. [CrossRef]

3. De Bary, A. Die Erscheinung der Symbiose: Vortrag, Gehalten auf der Versammlung Deutscher Natur-Forscher und Arzte zu Cassel; Verlag von Karl J. Trübner: Strasburg, Germany, 1879.

4. Van Beneden, P.J. Les Commensaux et les Parasites Dans le Règne Animal; Biblio Sci Int: Paris, France, 1875.

5. Famintsyn, A. Die Symbiose als Mittel der Synthese von Organismen. Biol. Zent. 1907, 27, 253-264.

6. Kozo-Polyansky, B. Symbiogenesis: A New Principle of Evolution, Translated by V. Fet; Fet, V., Margulis, L., Eds.; Harvard University Press: Cambridge, MA, USA, 2010.

7. Margulis, L. The Symbiotic Planet; Basic Books: New York, NY, USA, 1998.

8. Merezhkowsky, C. Über Natur und Ursprung der Chromatophoren im Pflanzenreiche. Biol. Zent. 1905, 25, 593-604, 689-691.

9. Sagan, L. On the origin of mitosing cells. J. Theor. Biol. 1967, 14, 255-274. [CrossRef]

10. Wallin, I.E. Symbionticism and the Origin of Species; Williams and Wilkins: Baltimore, MD, USA, 1927.

11. Keeling, P.J.; Palmer, J.D. Horizontal gene transfer in eukaryotic evolution. Nat. Rev. Genet. 2008, 9, 605-618. [CrossRef]

12. Zhaxybayeva, O.; Doolittle, W.F. Lateral gene transfer. Curr. Biol. 2011, 21, R242-R246. [CrossRef]

13. Lederberg, J. Infectious history. Science 2003, 288, 27. [CrossRef] [PubMed]

14. Shapiro, J.A. Mobile Genetic Elements; Academic Press: New York, NY, USA, 1983.

15. Shapiro, J.A. No genome is an island: Toward a 21st century agenda for evolution. Ann. N. Y. Acad. Sci. 2019, 1447, 21-52. [CrossRef]

16. Anderson, E. Origin of the angiosperms. Nature 1934, 133, 462. [CrossRef]

17. Stebbins, G.L. The significance of polyploidy in plant evolution. Am. Nat. 1940, 74, 54. [CrossRef]

18. Guerrero, R.; Margulis, L.; Berlanga, M. Symbiogenesis: The holobiont as a unit of evolution. Int. Microbiol. 2013, 16, 133-143. [CrossRef] 
19. Margulis, L. Symbiogenesis and symbionticism. In Symbiosis as a Source of Evolutionary Innovation; Margulis, L., Fester, R., Eds.; MIT Press: Cambridge, MA, USA, 1991; pp. 1-14.

20. Bapteste, E.; Huneman, P. Towards a dynamic interaction network of life to unify and expand the evolutionary theory. BMC Biol. 2018, 16, 56. [CrossRef] [PubMed]

21. Doolittle, W.F. Phylogenetic classification and the universal tree. Science 1999, 284, 2124-2129. [CrossRef] [PubMed]

22. Carrapiço, F. How symbiogenic is evolution? Theor. Biosci. 2010, 129, 135-139. [CrossRef] [PubMed]

23. Carrapiço, F. Can we understand evolution without symbiogenesis? In Reticulate Evolution; Gontier, N., Ed.; Springer: Cham, Switzerland, 2015; Volume 3, pp. 81-105. [CrossRef]

24. Douglas, A.E. The Symbiotic Habit; Princeton University Press: Princeton, NJ, USA, 2010.

25. Gontier, N. Symbiosis, History of. In Encyclopedia of Evolutionary Biology; Kliman, R., Ed.; Academic Press: Oxford, UK, 2016; Volume 4, pp. 272-282. [CrossRef]

26. Moran, N.A. Symbiosis as an adaptive process and source of phenotypic complexity. Proc. Natl. Acad. Sci. USA 2007, 104 (Suppl. 1), 8627-8633. [CrossRef]

27. Sapp, J. Evolution by Association: A History of Symbiosis; Oxford University Press: New York, NY, USA, 1994.

28. Sapp, J. The dynamics of symbiosis: An historical overview. Can. J. Bot. 2004, 82, 1046-1056. [CrossRef]

29. McDougall, W. The classification of symbiotic phenomena. Plant. World 1918, 21, 250-256.

30. Pfeffer, W. Physiology of Plants, English Edition Translated by AJ Ewart; Clarendon Press: Oxford, UK, 1899.

31. Van Beneden, P.J. Un mot sur la vie sociale des animaux inférieurs. Bull. Acad. R. Belg. 1873, 2, 779-796.

32. Toynbee, A.J. A Study of History, Somervell Abridgement of Vols. I-VI.; Oxford University Press: New York, NY, USA, 1947.

33. Haskell, E. Generalization of the structure of Mendeleev's periodic table. In Full Circle, The Moral Force of Unified Science; Haskell, E., Ed.; Gordon and Breach: New York, NY, USA, 1972; pp. 21-90.

34. Cowles, H.C. Hereditary symbiosis. Bot. Gaz. 1915, 59, 61-63. [CrossRef]

35. Von Faber, F.C. Das erbliche Zusammenleben von Bakterien und tropischen Pflanzen. Jahrb. Wiss. Bot. 1912, 51, III.

36. Buchner, P. Tier und Pflanze in Intrazellularer Symbiose; Gebrüder Borntraeger: Berlin, Germany, 1921.

37. Buchner, P. Symbiose der Tiere mit Pflanzlichen Mikroorganismen; De Gruyter: Berlin, Germany, 1939.

38. Schneider, A. The phenomena of symbiosis. Minn. Bot. Stud. 1897, 1, 923-948.

39. Roossinck, M. Even viruses can be beneficial microbes. Microbiol. Aust. 2012, 33, 111-112. [CrossRef]

40. Villarreal, L.P.; Witzany, G. Viruses are essential agents within the roots and stem of the tree of life. J. Theor. Biol. 2010, 262, 698-710. [CrossRef] [PubMed]

41. Prusiner, S.B. Molecular biology of prion diseases. Science 1991, 252, 1515-1522. [CrossRef]

42. Shapiro, J.A. Evolution: A View from the 21st Century; FT Press: Upper Saddle River, NJ, USA, 2011.

43. Corning, P.A. Systems theory and the role of synergy in the evolution of living systems. Syst. Res. 2014, 31, 181-196. [CrossRef]

44. Reinke, J. Zur Kenntniss des Rhizoms von Corallorhiza und Epipogon. Flora 1873, 31, 145-209.

45. Carrapiço, F. The origins of life and the mechanisms of biological evolution. In SPIE 6309, Instruments, Methods, and Missions for Astrobiology IX, Proceedings of the SPIE Optics + Photonics, San Diego, CA, USA, 14 September 2006; SPIE.Digital Library: Bellingham, DC, USA, 2006. [CrossRef]

46. Carrapiço, F. Azolla as a superorganism: Its implication in symbiotic studies. In Symbioses and Stress; Seckbach, J., Grube, M., Eds.; Springer: Dordrecht, The Netherlands, 2010; pp. 225-241. [CrossRef]

47. Lederberg, J. Cell genetics and hereditary symbiosis. Physiol. Rev. 1952, 32, 403-430. [CrossRef]

48. Koestler, A. The Ghost in the Machine; Penguin: London, UK, 1967.

49. Sapp, J. Genesis: The Evolution of Biology; Oxford University Press: New York, NY, USA, 2003.

50. Meyer-Abich, A. Beiträge zur Theorie der Evolution der Organismen I: Das typologische Grundgesetz und seine Folgerungen für Phylogenie und Entwicklungsphysiologie. Acta Biotheor. 1943, 7, 1-80. [CrossRef]

51. Meyer-Abich, A. Naturphilosophie auf Neuen Wegen; Hippokrates-Verlag Marquardt: Stuttgart, Germany, 1948.

52. Rosenberg, E.; Zilber-Rosenberg, I. The Hologenome Concept: Human, Animal and Plant Microbiota; Springer: Dordrecht, The Netherlands, 2013.

53. Gontier, N. Symbiogenesis, History of. In Encyclopedia of Evolutionary Biology; Kliman, R., Ed.; Academic Press: Oxford, UK, 2016; Volume 4, pp. 261-271. [CrossRef] 
54. Delwiche, C.F. Tracing the thread of plastid diversity through the tapestry of life. Am. Nat. 1999, 154, S164-S177. [CrossRef] [PubMed]

55. McFadden, G. Primary and secondary endosymbiosis and the origin of plastids. J. Phycol. 2001, 37, 951-959. [CrossRef]

56. McFadden, G.I.; van Dooren, G.G. Evolution: Red algal genome affirms a common origin of all plastids. Curr. Biol. 2004, 14, R514-R516. [CrossRef]

57. Martin, W.F.; Garg, S.; Zimorski, V. Endosymbiotic theories for eukaryote origin. Philos. Trans. R. Soc. Lond. B Biol. Sci. 2015, 370, 20140330. [CrossRef] [PubMed]

58. Livingstone Bell, P.J. Viral eukaryogenesis: Was the ancestor of the nucleus a complex DNA virus? J. Mol. Evol. 2001, 53, 251-256. [CrossRef] [PubMed]

59. Dunning Hotopp, J.C.; Clark, M.E.; Oliveira, D.C.; Jeremy, M.F.; Peter, F.; Mónica, C.M.T.; Jonathan, D.G.; Nikhil, K.; Nadeeza, I.; Shiliang, W.; et al. Widespread lateral gene transfer from intracellular bacteria to multicellular eukaryotes. Science 2007, 317, 1753-1756. [CrossRef] [PubMed]

60. Husnik, F.; McCutcheon, J.P. Functional horizontal gene transfer from bacteria to eukaryotes. Nat. Rev. Microbiol. 2018, 16, 67-79. [CrossRef]

61. Ryan, F. Virolution; Harper Collins: London, UK, 2009.

62. Danchin, E. Lateral gene transfer in eukaryotes: Tip of the iceberg or of the ice cube? BMC Biol. 2016, 14, 101. [CrossRef]

63. $\mathrm{Ku}, \mathrm{C}$.; Martin, W.F. A natural barrier to lateral gene transfer from prokaryotes to eukaryotes revealed from genomes: The $70 \%$ rule. BMC Biol. 2016, 14, 89. [CrossRef]

64. Avery, O.T.; MacLeod, C.M.; McCarty, M. Studies on the chemical nature of the substance inducing transformation of pneumococcal types. Induction of transformation by a deoxyribonucleic acid fraction isolated from pneumococcus type III. J. Exp. Med. 1944, 79, 137-158. [CrossRef]

65. Griffith, F. The significance of pneumococcal types. J. Hyg. (Lond.) 1928, 27, 113-159. [CrossRef]

66. Grohmann, E.; Muth, G.; Espinosa, M. Conjugative plasmid transfer in gram-positive bacteria. Microbiol. Mol. Biol. Rev. 2003, 67, 277-301. [CrossRef] [PubMed]

67. Lederberg, J.; Tatum, E.L. Gene recombination in E coli. Nature 1946, 158, 558. [CrossRef] [PubMed]

68. Lwoff, A. Lysogeny. Bacteriol. Rev. 1953, 17, 269-337. [CrossRef]

69. Morse, M.L.; Lederberg, E.M.; Lederberg, J. Transduction in Escherichia coli K-12. Genetics 1956, 41, $142-156$.

70. Zinder, N.D.; Lederberg, J. Genetic exchange in Salmonella. J. Bacteriol. 1952, 64, 679-699. [CrossRef] [PubMed]

71. Gontier, N. Historical and epistemological perspectives on what horizontal gene transfer mechanisms contribute to our understanding of evolution. In Reticulate Evolution; Gontier, N., Ed.; Springer: Cham, Switzerland, 2015; Volume 3, pp. 121-178. [CrossRef]

72. Haldane, J.B.S. Disease and evolution. Ric. Sci. Suppl. A 1949, 19, 68-76.

73. Gontier, N. Reticulate evolution everywhere. In Reticulate Evolution; Gontier, N., Ed.; Springer: Cham, Switzerland, 2015; Volume 3, pp. 1-40. [CrossRef]

74. Moreira, L.A.; Iturbe-Ormaetxe, I.; Jeffery, J.A.; Lu, G.; Pyke, A.T.; Hedges, L.M.; Rocha, B.C.; Hall-Mendelin, S.; Day, A.; Riegler, M.; et al. A Wolbachia symbiont in Aedes aegypti limits infection with dengue, Chikungunya, and Plasmodium. Cell 2009, 139, 1268-1278. [CrossRef]

75. Gilbert, S.F.; Sapp, J.; Tauber, A.I. A symbiotic view of life: We have never been individuals. Q. Rev. Biol. 2012, 87, 325-341. [CrossRef]

76. Griffiths, P. Time to consider the concept of a commensal virus? Rev. Med. Virol. 1999, 9, 73-74. [CrossRef]

77. Lecuit, M.; Eloit, M. The human virome: New tools and concepts. Trends Microbiol. 2013, 21, 510-515. [CrossRef]

78. Sapp, J. The New Foundations of Evolution; Oxford University Press: New York, NY, USA, 2009.

79. Tauber, A.I. The Immune Self: Theory or Metaphor? Cambridge University Press: Cambridge, UK, 1994.

80. Larson, J. The species concept of Linnaeus. Isis 1969, 59, 291-299. [CrossRef]

81. Stukenbrock, E.H. The role of hybridization in the evolution and emergence of new fungal plant pathogens. Phytopathology 2016, 106, 104-112. [CrossRef] [PubMed]

82. Eberlein, C.; Hénault, M.; Fijarczyk, A.; Chris, E.; Mathieu, H.; Anna, F.; Guillaume, C.; Matteo, B.; Linda, M.K.; James, B.A.; et al. Hybridization is a recurrent evolutionary stimulus in wild yeast speciation. Nat. Commun. 2019, 10, 923. [CrossRef] [PubMed] 
83. Taylor, S.A.; Larson, E.L.; Harrison, R.G. Hybrid zones: Windows on climate change. Trends Ecol. Evol. 2015, 30, 398-406. [CrossRef]

84. López-Caamal, A., II; Tovar-Sánchez, E. Genetic, morphological, and chemical patterns of plant hybridization. Rev. Chil. Hist. Nat. 2014, 87, 16. [CrossRef]

85. Mallet, J. Hybrid speciation. Nature 2007, 446, 279-283. [CrossRef]

86. Rieseberg, L.H. Hybrid origins of plant species. Annu. Rev. Ecol. Syst. 1997, 28, 359-389. [CrossRef]

87. Stebbins, G.L. Variation and Evolution in Plants; Columbia University Press: New York, NY, USA, 1950.

88. Abbott, R.; Albach, D.; Ansell, S.; Arntzen, J.W.; Baird, S.J.E.; Bierne, N.; Boughman, J.; Brelsford, A.; Buerkle, C.A.; Buggs, R.; et al. Hybridization and speciation. J. Evol. Biol. 2013, 26, 229-246. [CrossRef]

89. Anderson, E. Introgressive Hybridization; Wiley: New York, NY, USA, 1949.

90. Merezhkowsky, C. Theorie der zwei Plasmaarten als Grundlage der Symbiogenese, einer neuen Lehre von der Entstehung der Organismen. Biol. Zent. 1910, 30, 278-303, 321-347, 353-367.

91. Whittaker, R.H.; Margulis, L. Protist classification and the kingdoms of organisms. Biosystems 1978, 10, 3-18. [CrossRef]

92. Lutzoni, F.; Pagel, M.; Reeb, V. Major fungal lineages are derived from lichen symbiotic ancestors. Nature 2001, 411, 937-940. [CrossRef] [PubMed]

93. Hawksworth, D. The variety of fungal-algal symbioses, their evolutionary significance, and the nature of lichens. Bot. J. Linn. Soc. 1988, 96, 3-20. [CrossRef]

94. Honegger, R. Functional aspects of Lichen symbiosis. Annu. Rev. Plant. Physiol. Plant. Mol. Biol. 1991, 42, 553-578. [CrossRef]

95. Archibald, J.M.; Richards, T.A. Gene transfer: Anything goes in plant mitochondria. BMC Biol. 2010, 8, 147. [CrossRef] [PubMed]

96. Martin, W.; Herrmann, R.G. Gene transfer from organelles to the nucleus: How much, what happens, and Why? Plant. Physiol. 1998, 118, 9-17. [CrossRef]

97. Lederberg, E.M.; Lederberg, J. Genetic studies of lysogenicity in Escherichia coli. Genetics 1953, 38, 51-64.

98. Barondess, J.J.; Beckwith, J. bor gene of phage lambda, involved in serum resistance, encodes a widely conserved outer membrane lipoprotein. J. Bacteriol. 1995, 177, 1247-1253. [CrossRef]

99. Miajlovic, H.; Smith, S.G. Bacterial self-defense: How Escherichia coli evades serum killing. FEMS Microbiol. Lett. 2014, 354, 1-9. [CrossRef]

100. Burns, K.H. Our conflict with transposable elements and its implications for human disease. Annu. Rev. Pathol. 2020, 15, 51-70. [CrossRef]

101. McClintock, B. Chromosome morphology of Zey mays. Science 1929, 69, 629. [CrossRef]

102. McClintock, B. The origin and behavior of mutable loci in maize. Proc. Natl. Acad. Sci. USA 1950, 36, 344-355. [CrossRef] [PubMed]

103. Finnegan, D.J. Eukaryotic transposable elements and genome evolution. Trends Genet. 1989, 5, $103-107$. [CrossRef]

104. Gregory, R. A Word about 'Junk DNA'. Evolver Zone Genomicron. 2007. Available online: http://www. genomicron.evolverzone.com/2007/04/word-about-junk-dna (accessed on 1 January 2020).

105. Lotze, M.T.; Kost, T.A. Viruses as gene delivery vectors: Application to gene function, target validation, and assay development. Cancer Gene Ther. 2002, 9, 692-699. [CrossRef] [PubMed]

106. Arnold, M.L.; Ballerini, E.S.; Brothers, A.N. Hybrid fitness, adaptation and evolutionary diversification: Lessons learned from Louisiana Irises. Heredity (Edinb.) 2012, 108, 159-166. [CrossRef] [PubMed]

107. Green, R.; Krause, J.; Briggs, A.; Maricic, T.; Stenzel, U.; Kircher, M.; Patterson, N.; Li, H.; Zhai, W.; Hsi-Yang, M.; et al. A draft sequence of the Neanderthal genome. Science 2010, 328, 710-722. [CrossRef]

108. Prfüer, K.; De Filippo, C.; Grote, S.; Mafessoni, F.; Korlević, P.; Hajdinjak, M.; Vernot, B.; Skov, L.; Hsieh, P.; Peyrégne, S.; et al. A high-coverage Neandertal genome from Vindija Cave in Croatia. Science 2017, 358, 655-658. [CrossRef]

109. Prüfer, K.; Racimo, F.; Patterson, N.; Jay, F.; Sankararaman, S.; Sawyer, S.; Heinze, A.; Renaud, G.; Sudmant, P.H.; De Filippo, C.; et al. The complete genome sequence of a Neanderthal from the Altai Mountains. Nature 2013, 505, 43-49. [CrossRef]

110. Vernot, B.; Akey, J.M. Complex History of Admixture between Modern Humans and Neandertals. Am. J. Hum. Gene 2015, 96, 448-453. [CrossRef] 
111. Wall, J.D.; Yang, M.A.; Jay, F.; Kim, S.K.; Durand, E.Y.; Stevison, L.S.; Gignoux, C.; Woerner, A.; Hammer, M.F.; Slatkin, M. Higher Levels of Neanderthal Ancestry in East Asians than in Europeans. Genetics 2013, 194, 199-209. [CrossRef]

112. Chen, L.; Wolf, A.B.; Fu, W.; Li, L.; Akey, J.M. Identifying and Interpreting Apparent Neanderthal Ancestry in African Individuals. Cell 2020, 180, 677-687.e16. [CrossRef]

113. Vernot, B.; Akey, J.M. Resurrecting Surviving Neandertal Lineages from Modern Human Genomes. Science 2014, 343, 1017-1021. [CrossRef]

114. Dannemann, M.; Kelso, J. The Contribution of Neanderthals to Phenotypic Variation in Modern Humans. Am. J. Hum. Genet. 2017, 101, 578-589. [CrossRef] [PubMed]

115. Montgomery, M.K.; McFall-Ngai, M. Bacterial symbionts induce host organ morphogenesis during early postembryonic development of the squid Euprymna scolopes. Development 1994, 120, 1719-1729. [PubMed]

116. McFall-Ngai, M. The importance of microbes in animal development: Lessons from the squid-vibrio symbiosis. Annu. Rev. Microbiol. 2014, 68, 177-194. [CrossRef] [PubMed]

117. Lee, P.; McFall-Ngai, M.; Callaerts, P.; de Couet, G.H. Emerging model systems: The Hawaiian bobtail squid (Euprymna scolopes) as a model to study the molecular basis of eukaryote-prokaryote mutualism and the development and evolution of morphological novelties in cephalopods. Cold Spring Harb. 2009, 4, 1394-1402, 1471-1488.

118. Shibata, S.; Visick, K.L. Sensor Kinase RscS Induces the Production of Antigenically Distinct Outer Membrane Vesicles That Depend on the Symbiosis Polysaccharide Locus in Vibrio fischeri. J. Bacteriol. 2011, 194, 185-194. [CrossRef]

119. Visick, K.L.; Foster, J.; Doino, J.; McFall-Ngai, M.; Ruby, E.G. Vibrio fischeri lux Genes Play an Important Role in Colonization and Development of the Host Light Organ. J. Bacteriol. 2000, 182, 4578-4586. [CrossRef]

120. Altura, M.A.; Heath-Heckman, E.A.C.; Gillette, A.; Kremer, N.; Krachler, A.M.; Brennan, C.A.; Ruby, E.G.; Orth, K.; McFall-Ngai, M. The first engagement of partners in the Euprymna scolopes-Vibrio fischeri symbiosis is a two-step process initiated by a few environmental symbiont cells. Environ. Microbiol. 2013, 15, 2937-2950. [CrossRef]

121. Bongrand, C.; Ruby, E.G. The impact of Vibrio fischeri strain variation on host colonization. Curr. Opin. Microbiol. 2019, 50, 15-19. [CrossRef]

122. Kremer, N.; Koch, E.J.; El Filali, A.; Zhou, L.; Heath-Heckman, E.A.C.; Ruby, E.G.; McFall-Ngai, M.J. Persistent Interactions with Bacterial Symbionts Direct Mature-Host Cell Morphology and Gene Expression in the Squid-Vibrio Symbiosis. mSystems 2018, 3, e00165-18. [CrossRef]

123. Kremer, N.; Philipp, E.E.; Carpentier, M.-C.; Brennan, C.A.; Kraemer, L.; Altura, M.A.; Augustin, R.; Häsler, R.; Heath-Heckman, E.A.C.; Peyer, S.M.; et al. Initial symbiont contact orchestrates host-organ-wide transcriptional changes that prime tissue colonization. Cell Host Microbe 2013, 14, 183-194. [CrossRef] [PubMed]

124. Watanabe, T. Infective Heredity of Multiple Drug Resistance in Bacteria. Bacteriol. Rev. 1963, 27, 87-115. [CrossRef] [PubMed]

125. Iwasaki, W.; Takagi, T. Rapid Pathway Evolution Facilitated by Horizontal Gene Transfers across Prokaryotic Lineages. PLoS Genet. 2009, 5, e1000402. [CrossRef] [PubMed]

126. Ashley-Koch, A.E.; Yang, Q.; Olney, R.S. Sickle hemoglobin (HbS) allele and sickle cell disease: A HuGE review. Am. J. Epidemiol. 2000, 151, 839-845. [CrossRef] [PubMed]

127. Dieterich, W.; Schink, M.; Zopf, Y. Microbiota in the Gastrointestinal Tract. Med. Sci. 2018, 6, 116. [CrossRef]

128. Arnold, M.L.; Kentner, E.K.; Johnston, J.A.; Cornman, S.; Bouck, A.C. Natural hybridisation and fitness. TAXON 2001, 50, 93-104. [CrossRef]

129. Correns, C. Über Nichtmendelnde Vererbung. Z. Indukt. Abstamm. Vererb. 1928, I, 131-168.

130. Hagemann, R. Erwin Baur or Carl Correns: Who really created the theory of plastid inheritance? Am. Genet. Assoc. 2001, 91, 435-440. [CrossRef]

131. Carrapiço, F. Are bacteria the third partner of the Azolla-Anabaena symbiosis? In Advanced Structural Safety Studies; Polsinelli, M., Materassi, R., Vincenzini, M., Eds.; Springer: Dordrecht, The Netherlands, 1991; Volume 48, pp. 453-456.

132. Shropshire, J.D.; Bordenstein, S. Speciation by Symbiosis: The Microbiome and Behavior. mBio 2016, 7. [CrossRef] 
133. Bourtzis, K.; Nirgianaki, A.; Markakis, G.; Savakis, C. Wolbachia Infection and Cytoplasmic Incompatibility in Drosophila Species. Genetics 1996, 144, 1063-1073.

134. Sasaki, T.; Kubo, T.; Ishikawa, H. Interspecific transfer of Wolbachia between two lepidopteran insects expressing cytoplasmic incompatibility: A Wolbachia variant naturally infecting Cadra cautella causes male killing in Ephestia kuehniella. Genetics 2002, 162, 1313-1319. [PubMed]

135. Bouchon, D.; Rigaud, T.; Juchault, P. Evidence for widespread Wolbachia infection in isopod crustaceans: Molecular identification and host feminization. Proc. R. Soc. B Boil. Sci. 1998, 265, 1081-1090. [CrossRef] [PubMed]

136. Sheeley, S.L.; McAllister, B.F. Mobile male-killer: Similar Wolbachia strains kill males of divergent Drosophila hosts. Heredity 2009, 102, 286-292. [CrossRef] [PubMed]

137. Schilthuizen, M.; Stouthamer, R. Horizontal transmission of parthenogenesis-inducing microbes in Trichogramma wasps. Proc. R. Soc. B Boil. Sci. 1997, 264, 361-366. [CrossRef]

138. Vavre, F.; Fleury, F.; Lepetit, D.; Fouillet, P.; Bouletreau, M. Phylogenetic evidence for horizontal transmission of Wolbachia in host-parasitoid associations. Mol. Boil. Evol. 1999, 16, 1711-1723. [CrossRef]

139. Stouthamer, R.; Breeuwer, J.A.J.; Hurst, G.D.D. Wolbachia Pipientis: Microbial Manipulator of Arthropod Reproduction. Annu. Rev. Microbiol. 1999, 53, 71-102. [CrossRef]

140. Faria, V.G.; Sucena, É. Novel Endosymbioses as a Catalyst of Fast Speciation. In Reticulate Evolution; Gontier, N., Ed.; Springer: Cham, Switzerland, 2015; Volume 3, pp. 107-120.

141. Hurst, G.D.D.; Jiggins, F.M.; Von Der Schulenburg, J.H.G.; Bertrand, D.; West, S.A.; Goriacheva, I.I.; Zakharov, I.A.; Werren, J.H.; Stouthamer, R.; Majerus, M.E.N. Male-killingwolbachiain two species of insect. Proc. R. Soc. B Boil. Sci. 1999, 266, 735-740. [CrossRef]

142. Werren, J.H.; Baldo, L.; Clark, M.E. Wolbachia: Master manipulators of invertebrate biology. Nat. Rev. Genet. 2008, 6, 741-751. [CrossRef]

143. Archibald, J. One Plus One Equals One: Symbiosis and the Evolution of Complex Life; Oxford University Press: New York, NY, USA, 2014.

144. Sonneborn, T.M. Sex, Sex Inheritance and Sex Determination in Paramecium Aurelia. Proc. Natl. Acad. Sci. USA 1937, 23, 378-385. [CrossRef]

145. Preer, J.R.; Preer, L.B., Jr.; Jurand, A. Kappa and other endosymbionts in Paramecium aurelia. Bacteriol. Rev. 1974, 38, 113-163. [CrossRef]

146. Prince, A.L.; Chu, D.M.; Seferovic, M.D.; Antony, K.M.; Ma, J.; Aagaard, K. The Perinatal Microbiome and Pregnancy: Moving Beyond the Vaginal Microbiome. Cold Spring Harb. Perspect. Med. 2015, 5, a023051. [CrossRef] [PubMed]

147. Aagaard, K.; Ma, J.; Antony, K.M.; Ganu, R.; Petrosino, J.; Versalovic, J. The Placenta Harbors a Unique Microbiome. Sci. Transl. Med. 2014, 6, 237ra65. [CrossRef] [PubMed]

148. Mesa, M.-D.; Loureiro, B.; Iglesia, I.; Gonzalez, S.F.; Olivé, E.L.; Garcia-Algar, O.; Solana, M.J.; Perez, M.J.C.; Sainz, T.; Martinez, L.; et al. The Evolving Microbiome from Pregnancy to Early Infancy: A Comprehensive Review. Nutrients 2020, 12, 133. [CrossRef] [PubMed]

149. Ehrlich, P. Bemerkungen über die Immunität durch Vererbung und Säugung. Deut. Med. Wochenschr. 1892, 18, 511. [CrossRef]

150. Kordy, K.; Gaufin, T.; Mwangi, M.; Li, F.; Cerini, C.; Lee, D.J.; Adisetiyo, H.; Woodward, C.; Pannaraj, P.S.; Tobin, N.H.; et al. Contributions to human breast milk microbiome and enteromammary transfer of Bifidobacterium breve. PLoS ONE 2020, 15, e0219633. [CrossRef] [PubMed]

151. Muletz-Wolz, C.R.; Kurata, N.; Himschoot, E.; Wenker, E.; Quinn, E.A.; Hinde, K.; Power, M.L.; Fleischer, R.C. Diversity and temporal dynamics of primate milk microbiomes. Am. J. Primatol. 2019, 81, e22994. [CrossRef] [PubMed]

152. Blond, J.-L.; Besème, F.; Duret, L.; Bouton, O.; Bedin, F.; Perron, H.; Mandrand, B.; Mallet, F. Molecular Characterization and Placental Expression of HERV-W, a New Human Endogenous Retrovirus Family. J. Virol. 1999, 73, 1175-1185. [CrossRef] [PubMed]

153. Blond, J.-L.; Lavillette, D.; Cheynet, V.; Bouton, O.; Oriol, G.; Chapel-Fernandes, S.; Mandrand, B.; Mallet, F.; Cosset, F.L. An Envelope Glycoprotein of the Human Endogenous Retrovirus HERV-W Is Expressed in the Human Placenta and Fuses Cells Expressing the Type D Mammalian Retrovirus Receptor. J. Virol. 2000, 74, 3321-3329. [CrossRef]

154. Darwin, C. The Effects of Cross- and Self-Fertilization in the Vegetable Kingdom; John Murrey: London, UK, 1876. 
155. Shull, G.H. What Is 'Heterosis'? Genetics 1948, 33, 439-446.

156. Crow, J.F. 90 years ago: The beginning of hybrid maize. Genetics 1998, 148, 923-928.

157. Chen, Z.J. Molecular mechanisms of polyploidy and hybrid vigor. Trends Plant Sci. 2010, 15, 57-71. [CrossRef] [PubMed]

158. Waddington, C.H. Canalization of Development and Genetic Assimilation of Acquired Characters. Nature 1959, 183, 1654-1655. [CrossRef] [PubMed]

159. Eldredge, N.; Thompson, J.; Brakefield, P.; Gavrilets, S. The dynamics of evolutionary stasis. Paleobiology 2005, 31, 133-145. [CrossRef]

160. Rosenberg, E.; Zilber-Rosenberg, I. Symbiosis and development: The hologenome concept. Birth Defects Res. Part C Embryo Today Rev. 2011, 93, 56-66. [CrossRef] [PubMed]

161. Szathmáry, E.; Smith, J.M. The major evolutionary transitions. Nature 1995, 374, 227-232. [CrossRef]

162. Bradie, M. Assessing evolutionary epistemology. Boil. Philos. 1986, 1, 401-459. [CrossRef]

163. Buri, J.R.; Gunty, A.; Dukas, R.; Even, R.; Scheuer, O.; McLaren, B.M.; Okan, Z.; Everhart, D.E.; Schmidt-Kassow, M.; Hii, S.C.; et al. Evolutionary Epistemology. Encycl. Sci. Learn. 2012, I, 1193. [CrossRef]

164. Gontier, N. Evolutionary epistemology as a scientific method: A new look upon the units and levels of evolution debate. Theor. Biosci. 2011, 4, 515-538. [CrossRef]

165. Gontier, N. On How Epistemology and Ontology Converge Through Evolution: The Applied Evolutionary Epistemological Approach. In Extreme Events in Nature and Society; Wuppuluri, S., Doria, F.A., Eds.; Springer: Cham, Switzerland, 2018; pp. 533-569.

166. Feldhaar, H.; Gross, R. Genome degeneration affects both extracellular and intracellular bacterial endosymbionts. J. Boil. 2009, 8, 31. [CrossRef]

167. Fitzpatrick, D.A.; E Logue, M.; Butler, G. Evidence of recent interkingdom horizontal gene transfer between bacteria and Candida parapsilosis. BMC Evol. Boil. 2008, 8, 181. [CrossRef]

168. Shapiro, J.A. Constraint and opportunity in genome innovation. RNA Boil. 2013, 11, 186-196. [CrossRef] [PubMed]

169. Ullrich, S.R.; González, C.; Poehlein, A.; Tischler, J.S.; Daniel, R.; Schlömann, M.; Holmes, D.S.; Mühling, M. Gene Loss and Horizontal Gene Transfer Contributed to the Genome Evolution of the Extreme Acidophile "Ferrovum". Front. Microbiol. 2016, 7, 797. [CrossRef] [PubMed]

170. Caragata, E.P.; Rocha, M.N.; Pereira, T.N.; Mansur, S.B.; Dutra, H.L.C.; Moreira, L.A. Pathogen blocking in Wolbachia-infected Aedes aegypti is not affected by Zika and dengue virus co-infection. PLOS Negl. Trop. Dis. 2019, 13, e0007443. [CrossRef] [PubMed]

171. Mayr, E. The Growth of Biological Thought; Harvard University Press: Cambridge, MA, USA, 1982.

172. Brucker, R.M.; Bordenstein, S. Speciation by symbiosis. Trends Ecol. Evol. 2012, 27, 443-451. [CrossRef]

173. Mira, A.; Moran, N. Estimating Population Size and Transmission Bottlenecks in Maternally Transmitted Endosymbiotic Bacteria. Microb. Ecol. 2002, 44, 137-143. [CrossRef]

174. Telschow, A.; Hammerstein, P.; Werren, J.H. The effect of Wolbachia versus genetic incompatibilities on reinforcement and speciation. Evolution 2005, 59, 1607-1619. [CrossRef]

175. Werren, J.H. Wolbachia and speciation. In Endless Forms: Species and Speciation; Hoard, D., Berlocher, S., Eds.; Oxford University Press: Oxford, UK, 1998; pp. 245-260.

176. Dodd, D.M.B. Reproductive Isolation as a Consequence of Adaptive Divergence in Drosophila Pseudoobscura. Evolution 1989, 43, 1308-1311. [CrossRef]

177. Sharon, G.; Segal, D.; Ringo, J.M.; Hefetz, A.; Zilber-Rosenberg, I.; Rosenberg, E. Commensal bacteria play a role in mating preference of Drosophila melanogaster. Proc. Natl. Acad. Sci. USA 2010, 107, 20051-20056. [CrossRef]

178. Froebe, C.; Simone, A.; Charig, A.; Eigen, E. Axillary malodor production: A new mechanism. J. Soc. Cosmet. Chem. 1990, 41, 173-185.

179. Troccaz, M.; Gaïa, N.; Beccucci, S.; Schrenzel, J.; Cayeux, I.; Starkenmann, C.; Lazarevic, V. Mapping axillary microbiota responsible for body odours using a culture-independent approach. Microbiome 2015, 3, 3. [CrossRef]

180. Delzenne, N.; Bindels, L.B. Gut microbiota: Ganoderma lucidum, a new prebiotic agent to treat obesity? Nat. Rev. Gastroenterol. Hepatol. 2015, 12, 553-554. [CrossRef] [PubMed]

181. Inglis, J.E.; Ilich, J.Z. The Microbiome and Osteosarcopenic Obesity in Older Individuals in Long-Term Care Facilities. Curr. Osteoporos. Rep. 2015, 13, 358-362. [CrossRef] [PubMed] 
182. Liu, R.; Hong, J.; Xu, X.; Feng, Q.; Zhang, D.; Gu, Y.; Shi, J.; Zhao, S.; Liu, W.; Wang, X.; et al. Gut microbiome and serum metabolome alterations in obesity and after weight-loss intervention. Nat. Med. 2017, 23, 859-868. [CrossRef] [PubMed]

183. Turnbaugh, P.J.; Ley, R.E.; Mahowald, M.A.; Magrini, V.; Mardis, E.R.; Gordon, J.I. An obesity-associated gut microbiome with increased capacity for energy harvest. Nature 2006, 444, 1027-1031. [CrossRef]

184. Coello, K.; Hansen, T.H.; Sørensen, N.; Munkholm, K.; Kessing, L.V.; Pedersen, O.; Vinberg, M. Gut microbiota composition in patients with newly diagnosed bipolar disorder and their unaffected first-degree relatives. Brain Behav. Immun. 2019, 75, 112-118. [CrossRef]

185. Ng, Q.X.; Peters, C.; Ho, C.Y.X.; Lim, D.Y.; Yeo, W.-S. A meta-analysis of the use of probiotics to alleviate depressive symptoms. J. Affect. Disord. 2018, 228, 13-19. [CrossRef]

186. Schmidt, C. Mental health: Thinking from the Gut. Nature 2015, 518, S12-S14. [CrossRef]

187. Matsuura, K. Nestmate recognition mediated by intestinal bacteria in a termite, Reticulitermes speratus. Oikos 2001, 92, 20-26. [CrossRef]

188. Theis, K.R.; Venkataraman, A.; Dycus, J.A.; Koonter, K.D.; Schmitt-Matzen, E.N.; Wagner, A.P.; Holekamp, K.E.; Schmidt, T.M. Symbiotic bacteria appear to mediate hyena social odors. Proc. Natl. Acad. Sci. USA 2013, 110, 19832-19837. [CrossRef]

189. Tung, J.; Barreiro, L.; Burns, M.B.; Grenier, J.-C.; Lynch, J.; Grieneisen, L.E.; Altmann, J.; Alberts, S.C.; Blekhman, R.; Archie, E.A. Social networks predict gut microbiome composition in wild baboons. eLife 2015, 4, e05224. [CrossRef]

190. Papke, R.T.; Corral, P.; Ram-Mohan, N.; De La Haba, R.R.; Sánchez-Porro, C.; Makkay, A.; Ventosa, A. Horizontal Gene Transfer, Dispersal and Haloarchaeal Speciation. Life 2015, 5, 1405-1426. [CrossRef] [PubMed]

191. Nowell, R.W.; Green, S.; Laue, B.E.; Sharp, P.M. The extent of genome flux and its role in the differentiation of bacterial lineages. Genome Boil. Evol. 2014, 6, 1514-1529. [CrossRef]

192. Serrato-Capuchina, A.; Matute, D.R. The Role of Transposable Elements in Speciation. Genes 2018, 9, 254. [CrossRef] [PubMed]

193. Stapley, J.; Santure, A.W.; Dennis, S.R. Transposable elements as agents of rapid adaptation may explain the genetic paradox of invasive species. Mol. Ecol. 2015, 24, 2241-2252. [CrossRef] [PubMed]

194. Lin, X.-D.; Wang, W.; Guo, W.-P.; Zhang, X.-H.; Xing, J.-G.; Chen, S.-Z.; Li, M.-H.; Chen, Y.; Xu, J.; Plyusnin, A.; et al. Cross-Species Transmission in the Speciation of the Currently Known Murinae-Associated Hantaviruses. J. Virol. 2012, 86, 11171-11182. [CrossRef]

195. Lin, X.-D.; Wang, W.; Hao, Z.-Y.; Wang, Z.-X.; Guo, W.-P.; Guan, X.-Q.; Wang, M.-R.; Wang, H.-W.; Zhou, R.-H.; Li, M.-H.; et al. Extensive diversity of coronaviruses in bats from China. Virology 2017, 507, 1-10. [CrossRef]

196. Drosten, C.; Günther, S.; Preiser, W.; Van Der Werf, S.; Brodt, H.-R.; Becker, S.; Rabenau, H.; Panning, M.; Kolesnikova, L.; Fouchier, R.; et al. Identification of a Novel Coronavirus in Patients with Severe Acute Respiratory Syndrome. N. Engl. J. Med. 2003, 348, 1967-1976. [CrossRef]

197. Li, W. Bats Are Natural Reservoirs of SARS-Like Coronaviruses. Science 2005, 310, 676-679. [CrossRef]

198. Zaki, A.M.; Van Boheemen, S.; Bestebroer, T.; Osterhaus, A.; Fouchier, R. Isolation of a Novel Coronavirus from a Man with Pneumonia in Saudi Arabia. N. Engl. J. Med. 2012, 367, 1814-1820. [CrossRef]

199. Zhang, C.; Zheng, W.; Huang, X.; Bell, E.W.; Zhou, X.; Zhang, Y. Protein Structure and Sequence Reanalysis of 2019-nCoV Genome Refutes Snakes as Its Intermediate Host and the Unique Similarity between Its Spike Protein Insertions and HIV-1. J. Proteome Res. 2020, 19, 1351-1360. [CrossRef]

200. Zhou, P.; Yang, X.-L.; Wang, X.-G.; Hu, B.; Zhang, L.; Zhang, W.; Si, H.-R.; Zhu, Y.; Li, B.; Huang, C.-L.; et al. A pneumonia outbreak associated with a new coronavirus of probable bat origin. Nature 2020, 579, 270-273. [CrossRef] [PubMed]

201. Arnold, M.L. Hybrid Speciation. In Oxford Bibliographies Online Datasets; Oxford University Press (OUP): Oxford, UK, 2014.

202. Soltis, P.S.; Soltis, D.E. The Role of Hybridization in Plant Speciation. Annu. Rev. Plant Boil. 2009, 60, 561-588. [CrossRef] [PubMed]

203. Debodt, S.; Maere, S.; Vandepeer, Y. Genome duplication and the origin of angiosperms. Trends Ecol. Evol. 2005, 20, 591-597. [CrossRef] [PubMed] 
204. Wood, T.E.; Takebayashi, N.; Barker, M.S.; Mayrose, I.; Greenspoon, P.B.; Rieseberg, L.H. The frequency of polyploid speciation in vascular plants. Proc. Natl. Acad. Sci. USA 2009, 106, 13875-13879. [CrossRef] [PubMed]

205. Del Pozo, J.C.; Ramirez-Parra, E. Whole genome duplications in plants: An overview fromArabidopsis. J. Exp. Bot. 2015, 66, 6991-7003. [CrossRef] [PubMed]

206. Turrill, W.B. Solanum dulcamara and its inflorescence. Rep. Bot. Soc. Exch. Club Brit. Isles 1935, 11, 82-89.

207. Schmidt, K.P.; Huxley, J. Evolution the Modern Synthesis. Copeia 1943, 1943, 262. [CrossRef]

208. Van Valen, L. A new evolutionary law. Evol. Theor. 1973, 1, 1-30.

209. Benton, M. When Life Nearly Died: The Greatest Mass Extinction of All Time; Thames and Hudson: London, UK, 2005.

210. Min, K.-T.; Benzer, S. Wolbachia, normally a symbiont of Drosophila, can be virulent, causing degeneration and early death. Proc. Natl. Acad. Sci. USA 1997, 94, 10792-10796. [CrossRef]

211. Watson, A.J.; Lovelock, J.E. Biological homeostasis of the global environment: The parable of Daisyworld. Tellus B Chem. Phys. Meteorol. 1983, 4, 284-289. [CrossRef]

212. Boyle, R.A.; Lenton, T.M.; Watson, A. Symbiotic physiology promotes homeostasis in Daisyworld. J. Theor. Boil. 2011, 274, 170-182. [CrossRef] [PubMed]

213. Morran, L.T.; Schmidt, O.G.; Gelarden, I.A.; Parrish, R.C.; Lively, C.M. Running with the Red Queen: Host-Parasite Coevolution Selects for Biparental Sex. Science 2011, 333, 216-218. [CrossRef] [PubMed]

214. Weinbauer, M.; Rassoulzadegan, F. Review: Extinction of microbes: Evidence and potential consequences. Endanger. Species Res. 2007, 3, 205-215. [CrossRef]

215. Louca, S.; Shih, P.M.; Pennell, M.W.; Fischer, W.W.; Parfrey, L.W.; Doebeli, M. Bacterial diversification through geological time. Nat. Ecol. Evol. 2018, 2, 1458-1467. [CrossRef] [PubMed]

216. Methot, P.-O.; Alizon, S. Emerging Disease and the Evolution of Virulence: The Case of the 1918-1919 Influenza Pandemic. In Classification, Disease and Evidence; Huneman, P., Lambert, G., Silberstein, M., Eds.; Springer: Dordrecht, The Netherlands, 2014; Volume 7, pp. 93-130.

217. World Health Organization. Progress Report on HIV, Viral Hepatitis and Sexually Transmitted Infections 2019: Accountability for the Global Health Sector Strategies, 2016-2021; World Health Organization: Geneva, Switzerland, 2019; Available online: https:/apps.who.int/iris/handle/10665/324797 (accessed on 15 May 2020).

218. Ryan, F.P. Human endogenous retroviruses in health and disease: A symbiotic perspective. J. R. Soc. Med. 2004, 97, 560-565. [CrossRef]

219. Rhymer, J.M.; Simberloff, D. Extinction by Hybridization and Introgression. Annu. Rev. Ecol. Syst. 1996, 27, 83-109. [CrossRef]

220. Maheshwari, S.; Barbash, D.A. The Genetics of Hybrid Incompatibilities. Annu. Rev. Genet. 2011, 45, 331-355. [CrossRef]

221. Ereshefsky, M. The Poverty of the Linnaean Hierarchy: A Philosophical Study of Biological Taxonomy; Cambridge University Press: Cambridge, UK, 2001.

222. Gontier, N. Depicting the Tree of Life: The Philosophical and Historical Roots of Evolutionary Tree Diagrams. Evol. Educ. Outreach 2011, 4, 515-538. [CrossRef]

223. Vigliotti, C.; Bicep, C.; Bapteste, E.; Lopez, P.; Corel, E. Tracking the Rules of Transmission and Introgression with Networks. Microbiol. Spectr. 2018, 6, 345-365. [CrossRef]

224. Borges, R.M. Co-niche construction between hosts and symbionts: Ideas and evidence. J. Genet. 2017, 96, 483-489. [CrossRef]

(C) 2020 by the author. Licensee MDPI, Basel, Switzerland. This article is an open access article distributed under the terms and conditions of the Creative Commons Attribution (CC BY) license (http://creativecommons.org/licenses/by/4.0/). 